\title{
Spotting Areas Critical to Storm Waves and Surge Impacts on Coasts with Data Scarcity: A Case Study in Santa Catarina, Brazil
}

Karen Cristina Pazini ( $\sim$ pazini.k@gmail.com )

Universidade Federal de Santa Catarina https://orcid.org/0000-0003-0341-8077

Jarbas Bonetti

Universidade Federal de Santa Catarina

Paula Gomes da Silva

Universidad de Cantabria

Antonio Henrique da Fontoura Klein

Universidade Federal de Santa Catarina

\section{Research Article}

Keywords: CRAF, flooding, erosion, extreme events, coastal risk

Posted Date: May 6th, 2021

DOI: https://doi.org/10.21203/rs.3.rs-427549/v1

License: (a) (i) This work is licensed under a Creative Commons Attribution 4.0 International License.

Read Full License

Version of Record: A version of this preprint was published at Natural Hazards on February 26th, 2022.

See the published version at https://doi.org/10.1007/s11069-022-05275-1. 
1 Spotting areas critical to storm waves and surge impacts on coasts with data 2 scarcity: a case study in Santa Catarina, Brazil

3 Karen C. Pazini ${ }^{1 *}$, Jarbas Bonetti ${ }^{1}$, Paula Gomes da Silva ${ }^{1,2}$, Antonio Henrique da

4 Fontoura Klein ${ }^{1}$

$5{ }^{1}$ Coastal Oceanography Laboratory, Federal University of Santa Catarina, CEP: 88040-

6 000, Florianópolis, Santa Catarina, Brazil.

$7 \quad{ }^{2}$ Environmental Hydraulics Institute 'IH Cantabria', Universidad de Cantabria, C/Isabel

8 Torres $\mathrm{n}^{\circ} 15$ Parque Científico y Tecnolóogico de Cantabria, 39011, Santander, Spain.

$10 *$ Corresponding authors: Karen C. Pazini. E-mail address: pazini.k@gmail.com; Jarbas 11 Bonetti. E-mail address: jarbas.bonetti@ufsc.br

\section{ABSTRACT}

14 The impacts of severe storms on the coastal zone, combined with rapid population growth 15 in this area, has made coastal risk management an urgent need. However, integrated risk 16 assessment can be a challenging task for many locations worldwide, as it normally 17 requires the use of a large amount of data. The Coastal Risk Assessment Framework phase 18 one (CRAF1), is a recently proposed analytical scheme based on empirical models and 19 spatial analysis that combines different indicators to identify storm-induced hotspots. The methodology, however, requires accurate data at the regional scale and was conceived and validated for the European region. In this study, we show that this approach can be applied, with some simplifications, on data-poor areas, allowing the identification of hotspots considering one or multiple hazards. Here, the coastal risk was assessed for erosion and coastal flooding events with return periods of 10 and 50 years on the Santa Catarina Central Coast. The study area is characterized by the occurrence of storminduced impacts that historically cause disruption and damage to local communities. Although the components of risk have been assessed using various methods along this sector, to date, no integrated risk analysis has been presented in probabilistic terms. Predicted scenarios for the Santa Catarina Central Coast suggest that extreme episodes may cause several impacts, exposing urban settlements as well local road systems, especially in the municipalities of Tijucas and Florianópolis. The results show that the CRAF1 is an appropriate approach for a first-level risk analysis, even when implemented with poor data resolution, as it effectively points to some of the most vulnerable stretches detected in the study area. 
KEYWORDS

CRAF, flooding, erosion, extreme events, coastal risk

\section{INTRODUCTION}

Storm-induced waves and surges can be considered among the most important drivers of coastal flooding and erosion, often interrelated impacts that affect most locations worldwide (Kron, 2013; Von Storch, 2014). During extreme conditions, these hydrometeorological events can produce significant changes in the coastal zone in a very short period (Morton et al., 1995), leading to economic losses and, eventually, risk to human life.

Furthermore, future projections show that storm-induced impacts will substantially increase over the years on some coasts of the world, due to climate changes and rising sea levels (Vousdoukas et al., 2018; Kirezci et al., 2020).

In this scenario, an assessment of current and future risk is required to support coastal management and policy implementation. Risk assessment is particularly important for developing countries, in which reduced resilience means the population is exposed to more severe consequences of flood and erosion than those living in developed regions (Church et al., 2008; Hanson et al., 2011; Neumann et al., 2015; UNISDR, 2018). Estimating risk in these areas can be challenging though, as data are often unavailable or present poor resolution.

The southern region of Brazil is historically affected by storm-induced waves and surges, often associated with the passage of cold fronts and extra tropical cyclones (Parise et al., 2009). On the coast of Santa Catarina state, episodes of flooding and erosion linked to these events are recurrent and have caused serious damage to the local community (Rudorff et al., 2014).

Considering the high level of exposure of the population and urban assets along the Santa Catarina Central Coast, as demonstrated by several previous studies in the area on the local scale (Mazzer et al., 2008; Rudorff and Bonetti, 2010; Muler and Bonetti, 2014; Klein et al., 2016a; Mussi et al., 2018; Santos and Bonetti, 2018; Silveira and Bonetti, 2019; Lima and Bonetti, 2020) and regional scales (CEPAL, 2012; Serafim and Bonetti, 2017; Bonetti et al., 2018; Serafim et al., 2019), this research aimed to assess the most critical sectors, considering the different levels of risk to which the coastline is submitted. 
This is a novel approach, since most of the existing research is focused on vulnerability and does not take into account the probability of the impact of coastal hazards in different time-frames. The study also prioritizes the identification of hotspots in the management unit proposed in the Brazilian Coastal Management Program sectorization, which facilitates the applicability of results by decision-makers.

Moreover, the applied methodology (the Coastal Risk Assessment Framework phase one; CRAF1) was originally designed for the European context, and despite its implementation in different coastal settings (cf. Armaroli and Duo, 2018; Aucelli et al., 2018; Christie et al., 2018; De Angeli et al., 2018; Jiménez et al., 2018; Plomaritis et al., 2018), this framework has never been tested in a condition of data scarcity. In this paper, the CRAF framework was applied in an area with incipient spatial data infrastructure and lowresolution spatial information, which is also the case in several nations around the world. For this, our paper proposes an adaptation in the use of the originally recommended risk descriptors as the main strategy to overcome the aforementioned data limitation.

Here, the tool was applied with simplifications to the area of interest, and the critical sectors were identified through a combination of empirical methods and spatial analysis, highlighting, in a comparative way, priority areas for management actions and providing a valuable information basis for further detailing.

Considering that vulnerability-related terminology varies widely among researchers, which reflects the lack of consensual definitions for such terms (Bonetti and Woodroffe, 2017), it is worth clarifying that, in this study, risk is defined as the product of the probability occurrence of a hazard and its consequences (UNISDR, 2009). Susceptibility expresses the natural potential level of losses associated with the characteristics of the hazard, and vulnerability is defined as the propensity of a receptor (human assets; ecosystems) to suffer damage (Viavattene et al., 2015). In addition, the term exposure is applied to express the direct and indirect losses that receptors may have in contact with the hazard.

This article is structured as follows: section 2 describes the study area and the available data; section 3 presents the first phase of the CRAF1 framework and the simplifications adopted to allow the implementation of the method to the study site; section 4 shows the results; section 5 discusses the hotspots identified and finally, section 6 summarizes the main conclusions of the work. 
99 The area of interest of this work is located in South Brazil and comprises the beaches of 100 the Santa Catarina Central Coast (SC-CC), according to the sectorization proposed by the 101 Brazilian Coastal Management Program (Santa Catarina, 2006) (Fig. 1). Waves and storm 102 surges affect the beaches located inside the sheltered coastline between Santa Catarina 103 Island and the mainland differently (Mussi et al., 2018; Silveira and Bonetti, 2019), and 104 hence this sector of the coast was not considered in the analysis. The southern sector of 105 Tijucas municipality coastline has not been analysed either, since it is a tide-dominated beach with an upper shoreface basically composed of mud flats, which induce a particular hydrodynamical behaviour to this sector (Klein et al., 2016b).

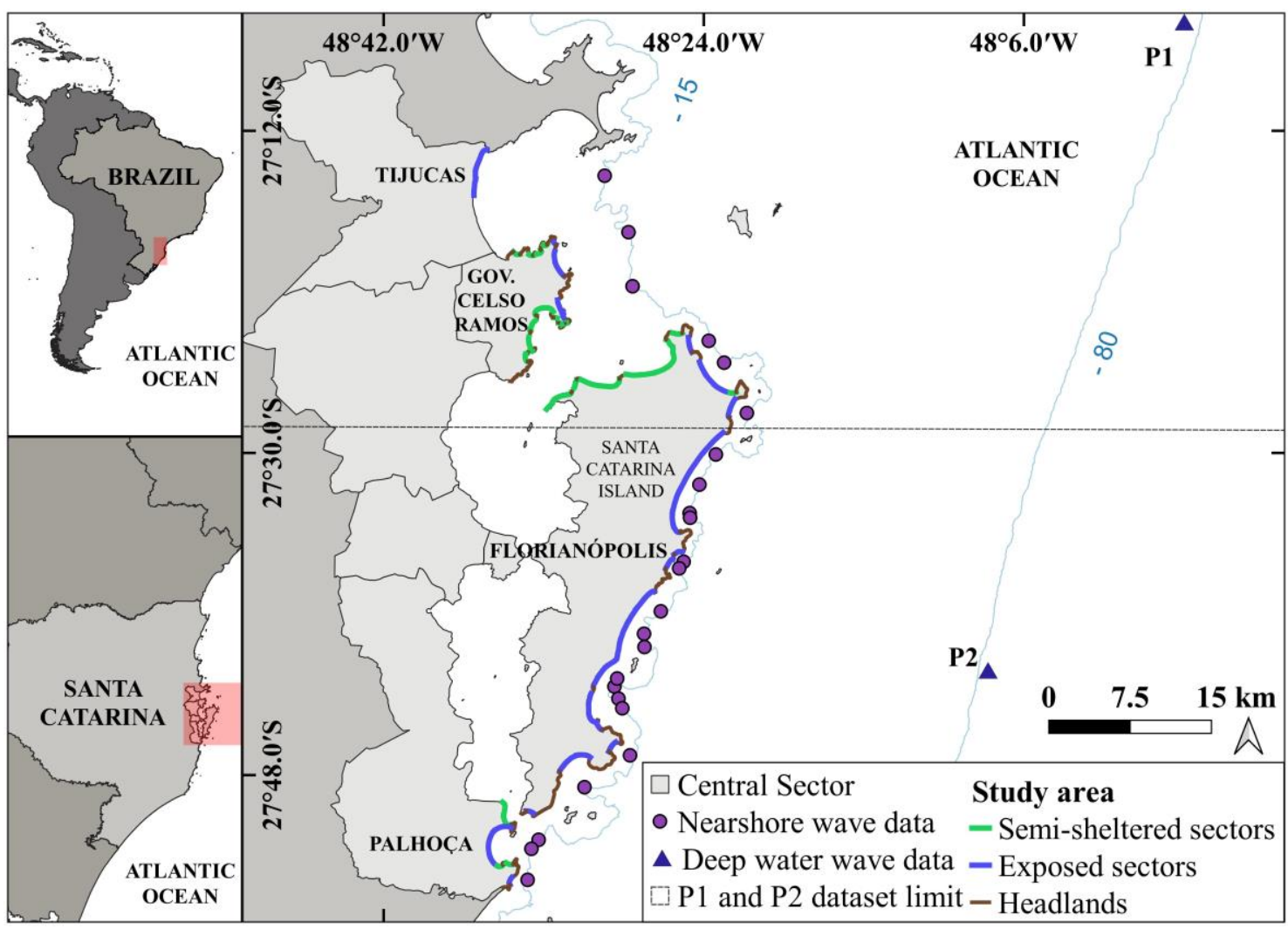

Fig. 1 Location of the Santa Catarina Central Coast with sectors classified according to their degree of exposure to the main wave direction. The points used for wave data extraction are also represented.

113 The area covers more than $100 \mathrm{~km}$ of coastline and includes the state capital, 114 Florianópolis, and the municipalities of Palhoça, Governador Celso Ramos and Tijucas

115 (Fig. 1). This is the most densely populated coastal region of the Santa Catarina state and 116 is where important economic activities related to tourism, fishing, aquaculture and diverse 117 industries stand out (Santa Catarina, 2010). 
118 The Santa Catarina coast is exposed to waves from four main directions: low-energy

119 conditions usually coming from the northeast quadrant, and high-energy waves arriving

120 from east, south and southeast, with significant heights up to $6 \mathrm{~m}$ and a recorded

121 maximum of 13 m individual height (Araújo et al., 2003; Melo Filho et al., 2006).

122 This coastal zone has a microtidal regime, with spring tides ranging from $1.05 \mathrm{~m}$ in the 123 north to 0.46 in the south (Klein et al., 2016b), whereas the meteorological component of 124 the water level (storm surge) can be as high as $1 \mathrm{~m}$ (Truccolo et al., 2006).

125 The central coast of Santa Catarina state presents a high economic value, offering important goods and services (Scherer and Asmus, 2016). Nonetheless, this area is particularly prone to storm induced impacts, which cause serious property damage and demand a large amount of financial investment by the government, as highlighted by several studies (Simó and Horn Filho, 2004; Horn Filho, 2006; Rudorff et al., 2014; Klein et al., 2016b).

\subsection{Data}

132 The topography and bathymetry were characterized using the Digital Terrain Model 133 available from the state's 'Secretaria de Estado do Desenvolvimento Econômico 134 Sustentável (SDS)', with a $1 \mathrm{~m}$ horizontal resolution and $2.5 \mathrm{~m}$ altimetric accuracy (Souza 135 et al., 2017) and from nautical charts produced by the Brazilian Navy's 'Diretoria de 136 Hodrografia e Navegação’ (DHN). Possible discrepancies regarding the different datums 137 used for topography and bathymetry charting were minimized as proposed by Klein et al. 138 (2016a). Beach morphology and sediment grain sizes along the coast were acquired in the 139 field in the scope of the project RIMPEEX-Sul '(Rede Integrada de Monitoramento e 140 Previsão de Eventos Extremos na Região Sul'; Bonetti et al., 2018).

141 Wave and water level data were obtained from the Regional Ocean Waves (ROW) and 142 Global Ocean Surge and Tide (GOST) databases, a reanalysis dataset specifically 143 validated for Santa Catarina coast (Rodríguez and Lasa, 2016) that include a 31-year 144 period (1979-2010) with hourly temporal resolution.

145 Regarding the analysis of coastal exposure, the land-use data for the study area was 146 provided by Mussi (2017); the socio-economic information was obtained from the IBGE 147 (2011) census (see details in Supplementary Material, Annex A); the transport system 148 was characterized with information supplied by DEINFRA (2018) and OpenStreetMap 
149 platform (OSMF, 2018); the business information was obtained from SEAP (2008) and

150 finally, the utility information was extracted from CNES (2018) and SED-SC (2018).

\section{METHODOLOGICAL FRAMEWORK}

152 The tool CRAF1 was applied to identify critical points in terms of coastal flooding and

153 erosion risk. The flowchart in Fig. 2 summarizes the adopted methodological approach.

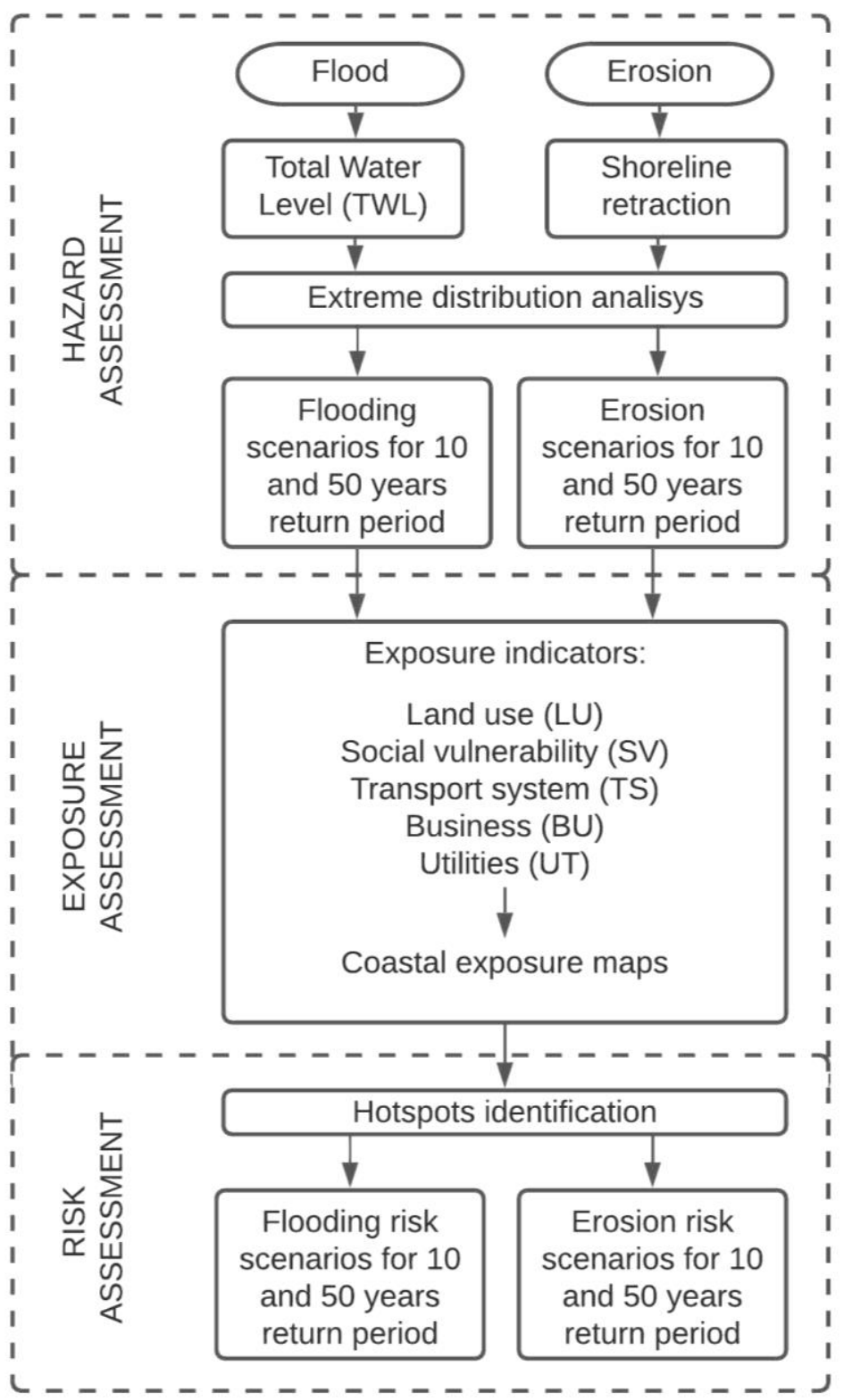

Fig. 2 Methodological flowchart of the risk assessment performed in this research.

157 The methodology consists of a screening process that allows the identification of hotspots

158 on a large spatial scale by assessing the potential impacts for every coastal sector of approximately $1 \mathrm{~km}$ along the shore length. The approach combines different hazard 
160 effects $\left(i_{h}\right)$ and exposure $\left(I_{\text {exp }}\right)$ indicators into a single value, the Coastal Index (CI), which

161 is estimated for each sector (equation 1) (Viavattene et al., 2018):

$$
C I=\sqrt{i_{h} * i_{\text {exp }}}
$$

163 Here, two types of hazard effects are considered: flood and erosion. It was not possible

164 to apply the recommended level of analytic detail, especially in the hazard assessment 165 model, due to the non-existence of a DTM and a bathymetric chart with a fine grid and 166 high resolution to obtain the morphological parameters at the land-ocean interface. 167 Moreover, despite having a long time series of wave and water level data, several 168 hydrodynamic parameters required for the application of the chosen empirical models had 169 to be simplified, as the lack of regular bathymetry data makes it difficult to take into 170 account the wave transformation and attenuation process in shallow waters. A 171 comparative review showing the main challenges faced when applying the tool in the

172 study area in its simplified form is presented in the supplementary material, Annex B.

173 The magnitude and extent of the different hazard effects and exposure indicators were computed separately following some assumptions and found alternatives, as described in the next sections.

\subsection{Coastal hazard assessment}

177 To estimate $i_{h}$, the magnitude of the hazard effect must be computed for a certain return 178 period by using empirical models and converted to a hazard scale from 0 to 5 (none, very 179 low, low, medium, high, and very high). To this end, the study area was divided into 83 180 representative sectors, each one covering up to a $2.5-\mathrm{km}$ length of sandy beaches.

181 As the impact driver is strongly dependent on storm wave direction and shoreline 182 orientation (Masselink et al., 2016), the sectors were classified according to the degree of exposure to the main wave directions that reach Santa Catarina Island: South, Southeast and East. When possible, the classification presented here was based on previous studies

185 (Muler \& Bonetti, 2014; Klein et al., 2016a; Klein et al. 2016b). Otherwise, the simple 186 relation between the shoreline orientation and the main wave direction was taken into 187 account for the categorization. Hereafter, 'exposed sectors' refer to the sectors exposed 188 to waves, where there is a high angle of incidence between the main wave direction and 189 the coastline, and 'semi-sheltered' sectors refer to those sectors where waves have small or no effect on flooding/erosion (see Fig. 1). 
192 The magnitude of flooding was estimated through the extreme distribution of the total water level, the storm surge, and the wave runup. The storm-induced run-up was computed by applying the formula proposed by Holman (1986), which considers the significant wave height, the wave length and the beach face slope. The semi-sheltered sectors were assumed to be influenced little or very little by wave action. Therefore, in this case, the wave run-up was not taken into account. Moreover, the Total Water Level (TWL) dataset was obtained by using deep water wave data (Fig. 1).

TWL time series were fitted to the G.E.V. (Generalized Extreme Value) distribution using annual maxima values. The analysis was carried out in IH-AMEVA (IH-Cantabria, 2013), and the extreme water levels associated to return periods of 10 (T10) and 50 (T50) years were used to characterize different scenarios.

The area potentially flooded by those extreme events was delineated by using the bathtub approach, which consists in assuming that all areas connected to the sea with an elevation below the TWL will be flooded (Viavattene et al., 2018). In the geographic information system (GIS) environment, the outlined surface was computed for each sector, considering the beach topography and the corresponding water level for the selected return periods. Finally, a simple rectangle generated from the maximum flood potential in each sector was used to illustrate the potential 'hazard extent' (according to the terminology adopted by the RISC-KIT assessment framework; Viavattene et al., 2015).

\subsubsection{Erosion}

212 Erosion was assessed in the exposed areas using the model of Kriebel and Dean (1993).

213 This model proposes an adaptation of the Bruun rule (1954) to estimate the changes in 214 the beach profile due to storm waves, and the respective coastline retreat/advance. The maximum potential retreat $(R \infty)$ is expressed by Bruun (1954) as (Equations 3 and 4):

$$
\begin{aligned}
& R_{\infty}=\frac{S X_{b}}{B+h b-S / 2}, \\
& X_{b}=\left(\frac{h_{b}}{A}\right)^{3 / 2},
\end{aligned}
$$

218 where $S$ is the water level variation, $h b$ is the wave-breaking depth, $B$ is the frontal dune

219 height, $X_{b}$ is the distance from the wave-breaking depth and $A$ is the parameter related to 220 the sediment size that characterizes the profile slope. 
221 According to Kriebel and Dean (1993), as the beach profile changes obtained from

222 Brunn's model represent a slow response to the water level variation, a proportional and rapid retreat due to storms must be determined taking into account the characteristic time scale of the exponential response $(T s)$ and the storm duration $(T D)$. Ts was computed with equation 5, whereas $T D$ was assumed to be the typical storm duration in the study area, a value obtained from the literature (see Table 1).

$$
T_{S}=\frac{320 x H_{b}^{\frac{3}{2}}}{A^{3} g^{1 / 2}\left(1+\frac{h_{b}}{B}+\frac{m x_{b}}{h_{b}}\right)},
$$

Where $H b$ is the wave-breaking height; $g$ is the gravitational acceleration; and $m$ is the beach profile slope.

231 Finally, the proportional retreat $(R)$ over time $(t)$ was calculated from the maximum

232 potential retreat $(R \infty)$ as a function of $\beta$ (the ratio between the erosion time scale and the 233 storm duration) (Equations 6, 7 and 8):

$$
\frac{R(t)}{R_{\infty}}=\frac{1}{2}\left\{1-\frac{\beta^{2}}{1+\beta^{2}} \exp \left(\frac{-2 \sigma t}{\beta}\right)-\frac{1}{1+\beta^{2}}[\cos (2 \sigma t)+\beta \sin (2 \sigma t)]\right\}
$$

$$
\begin{gathered}
\beta=2 \pi \frac{T_{S}}{T_{D}}, \\
\sigma=\frac{\pi}{T_{D}} .
\end{gathered}
$$

238 Data used to compute the shoreline retreat are shown in table 1. The biggest challenge to applying the chosen empirical model was the scarcity of detailed topography and bathymetry data on a regional scale, which allows the extraction of parameters related to the morphodynamics of sandy beaches, such as the depth of closure and the beach profile 242 slope.

243 Therefore, these parameters were estimated empirically according to the following 244 simplifications: first, the depth of closure was computed using the formula proposed by 245 Hallermeier (1978). For this purpose, nearshore wave data were extracted from the GOST 246 database at a depth of $15 \mathrm{~m}$, positioned in front of the exposed sectors (see Fig. 1). 247 Afterwards, the cross-shore distance from the shoreline was obtained through Dean's 248 equilibrium profile equation (1977). The parameter that defines the profile slope $(A)$ 249 required in this stage was estimated according to the empirical approach proposed by 
250 Dean (1987), considering $k=0.51$. Finally, the beach profile slope was computed using 251 trigonometric relations between the deep of closure and its respective distance from the 252 coast.

253 The breaking-wave height $(H b)$ and break-wave depth $(h b)$ time series were also obtained 254 empirically by employing the formula proposed by Komar and Gaughan (1972) and 255 Weggel (1972), respectively. Furthermore, in specific situations of erosion hazard in the 256 absence of dunes, the dune height ( $0 \mathrm{~m}$ in this case) was set to $0.2 \mathrm{~m}$, to allow a hazard 257 assessment.

258 The computed time series of shoreline retreat were fitted to a G.E.V. function, and the 259 values associated with the selected return periods were obtained. The hazard extent was 260 outlined by a $50 \mathrm{~m}$ buffer zone from the maximum shoreline retreat in each scenario. The 261 buffer value, first proposed by Mazzer et al. (2008), was chosen on the basis of the 262 minimum-security distance considered by the ORLA project (MMA, 2004) for management purposes along the entire Brazilian coast.

Table 1. Data used to compute the storm-induced shoreline retreat.

\begin{tabular}{|c|c|c|}
\hline Data & Source & $\begin{array}{c}\text { Range of values for the } \\
\text { exposed sectors }\end{array}$ \\
\hline Frontal dune height $(B)$ & \multirow{2}{*}{$\begin{array}{l}\text { RIMPEEX-Sul Project } \\
\text { (Bonetti et al., 2018) }\end{array}$} & $0.2-4.0(\mathrm{~m})$ \\
\hline and sediment sizes $\left(D_{50}\right)$ & & $0.17-1.36(\mathrm{~mm})$ \\
\hline Beach-profile slope $(\mathrm{m})$ & trigonometric relations & $0.01-0.06(\mathrm{rad})$ \\
\hline $\begin{array}{l}\text { Parameter governing the } \\
\text { profile steepness }(A)\end{array}$ & $\begin{array}{l}\text { empirical approach } \\
\text { (Dean, 1987) }\end{array}$ & $0.09-0.23$ \\
\hline Breaking-wave height $(H b)$ & \multirow{2}{*}{$\begin{array}{c}\text { empirical approaches: } \\
\text { Komar and Gaughan (1973) } \\
\text { and Weggel (1972) }\end{array}$} & $6.4-7.2(\mathrm{~m})$ \\
\hline Break-wave depth $(h b)$ & & $6.1-8.4(\mathrm{~m})$ \\
\hline Water-level variation $(S)$ & $\begin{array}{l}\text { TWL computed for each } \\
\text { scenario }\end{array}$ & $1.7-6.6(\mathrm{~m})$ \\
\hline Storm duration $(T D)$ & $\begin{array}{c}\text { Piçarras Project } \\
\text { (Dalinghaus et al., 2015) }\end{array}$ & 192 (hours) \\
\hline
\end{tabular}

\subsubsection{Hazard-impact indicator $\left(i_{h}\right)$}

267 The hazard-impact indicator was attributed individually for each hazard and each sector along the coast. To obtain the flood-impact indicator, the maximum extent of the flooding scenario was subtracted from the corresponding beach width. The resulting extent was 
then scored as shown in table 2. Negative values indicate areas where the extent of

271 flooding is restricted to the beach; therefore, the hazard index is null. Positive values indicate areas where the TWL exceeds the backshore, and the hazard-impact indicator increases progressively with extent of enlargement.

Table 2. Classification of the hazard-impact indicators $\left(i_{h}\right)$ according to the intervals of flooding/erosion extent

\begin{tabular}{c|c|c|c}
\hline $\begin{array}{c}\text { Extent of } \\
\text { flooding T10 } \\
\text { and T50 (m) }\end{array}$ & $\begin{array}{c}\text { Extent of } \\
\text { erosion } \\
\text { T10 (m) }\end{array}$ & $\begin{array}{c}\text { Extent of } \\
\text { erosion } \\
\text { T50 (m) }\end{array}$ & $\begin{array}{c}\text { Hazard- } \\
\text { impact } \\
\text { indicator }\end{array}$ \\
\hline$-20-0.0$ & $0.0-0.2$ & $0.0-19.2$ & 0 \\
\hline $0.0-100$ & $0.2-0.4$ & $19.2-41.5$ & 1 \\
\hline $100-200$ & $0.4-0.7$ & $41.5-54.8$ & 2 \\
\hline $200-300$ & $0.7-1.4$ & $54.8-70.6$ & 3 \\
\hline $300-400$ & $1.4-3.4$ & $70.6-126.3$ & 4 \\
\hline$>400$ & $>3.4$ & $>126.3$ & 5 \\
\hline
\end{tabular}

276

277 The erosion-impact indicator was attributed by ranking the shoreline retreat values (see 278 table 2). This time, scores were assigned differently for T10 and T50 due to discrepancies 279 between the ranges of values. The Natural Breaks segmentation method (Jenks and 280 Caspall, 1971) was used to obtain the categorization in each scenario.

\subsection{Coastal exposure assessment}

282 The exposure analysis consisted of determining a General Exposure Indicator $\left(I_{\text {exp }}\right)$, 283 which is composed of different types of receptors: Land Use (LU), Social Vulnerability 284 (SV), Transport System (TS), Business (BU) and Utilities (UT). The $I_{\text {exp }}$ is estimated by 285 (equation 9):

$$
I_{\text {exp }}=\left(i_{1} * i_{2} * \ldots i_{n}\right)^{1 / n},
$$

287 Where $n$ is the number of the considered types of receptors.

288 The exposure assessment was carried out individually for each hazard impact and 289 scenario. The five exposure categories were evaluated according to specific methods as 290 described in this section, then ranked from 1 to 5 (None or Very Low, Low, Medium, 291 High and Very High) before the overall integration. In the same way, the $I_{\text {exp }}$ was scored 
292 into five categories and then reclassified from 1 to 5 . The obtained values are registered 293 in Annex C (Supplementary material).

$294 \quad 3.2 .1 \quad$ Land Use (iexp_LU)

295 This indicator measures the relative exposure of different land uses along the coast, 296 considering the area and the importance of the land use class for human activities. Based

297 on the scale developed by Perini et al. (2016), each class received a representative value 298 from 1 to 4 . Therefore, areas with a high degree of human activity, such as urban 299 settlements and croplands, were considered critical and received higher exposure values 300 (4 and 3), while areas with little or no human activity such as sandy beaches, dunes, 301 forests and mangroves received lower exposure values (2 and 1). Details are presented in 302 in Supplementary Material, Annex D.

303 In each sector, the land use indicator was estimated according to (equation 10):

$$
I_{\text {exp_LU }}=\sum_{i}^{n} \frac{V * A_{i}}{A_{t}}
$$

305 Where $V$ is the value assigned to the class, $A i$, the area occupied by the class and $A t$, the 306 total area of the sector.

$307 \quad 3.2 .2$ Social Vulnerability (iexp_SV)

308 The Social Vulnerability exposure indicator (iexp_SV) measures the relative exposure of

309 different communities along the coast, considering their socio-economic characteristics

310 according to the most common indicators used in the literature (Lima and Bonetti, 2020).

311 The iexp_SV was computed on the basis of a Social Vulnerability Index (SVI) built for 312 the Santa Catarina Central Sector. To build the SVI, six components were considered, as 313 presented in table 3.

Table 3. Components used to construct the SVI

\begin{tabular}{c|c}
\hline Categories & Components \\
\hline \multirow{2}{*}{$\begin{array}{c}\text { Financial } \\
\text { deprivation }\end{array}$} & \begin{tabular}{c} 
Percentage of households living in poverty \\
\cline { 2 - 2 }
\end{tabular} \\
\hline Education & Percentage of literate household heads $\left(C_{s v}\right)$ \\
\hline Household & Number of residents per household $\left(D_{s v}\right)$ \\
structure & \\
\hline
\end{tabular}




\begin{tabular}{c|c}
\hline Gender & $\begin{array}{c}\text { Percentage of households headed by young } \\
\text { women }\left(E_{s v}\right)\end{array}$ \\
\hline Age & Vulnerable age group $\left(F_{s v}\right)$ \\
\hline
\end{tabular}

316 In order to enable the integration of components, the values obtained were standardized,

317 and the SVI was determined following the approach proposed by Tapsell et al. (2002).

318 The original equation was adapted to summarize the four chosen categories (see table 3):

319 financial deprivation, education, household structure, gender and age (equation 11).

$$
S V I=0.5\left(A_{s v}+B_{s v}\right)+C_{s v}+D_{s v}+E_{s v}+F_{s v}
$$

321 Finally, to compute the iexp_SV, the procedure described in item 3.2.1 (Equation 10)

322 was performed.

\subsubsection{Transport system (iexp_TS), Business (iexp_BU) and Utilities (iexp_UT)}

These indicators are considered to better represent the exposure of structures, which can lead to systemic impacts or to a higher order of losses. Each one was represented by points in a GIS environment and quantified at the sectorial level with the Spatial Join resource. They were subsequently computed in terms of density, dividing the number of points by the total area of the sector.

The transport system indicator was estimated as the density of roads and local road networks in each sector. The business indicator was determined accounting for the number of establishments linked to commercial, industrial and agricultural activities in each sector, and finally, the utility indicator was defined by the number of health (hospital and clinics) and education units in the area of the hazard impact extent. Other utilities suggested by CRAF1 methodology (e.g. drinking water intake and electrical transmission substations) were not observed within the extent of the hazard areas.

\subsection{Identification of hotspot areas}

337 Hotspots were identified through application of the Coastal Index, which was computed 338 for each hazard impact and each associated return period. The relation between the hazard 339 impact indicator $\left(i_{h}\right)$ and the general exposure indicator $\left(I_{\text {exp }}\right)$ was established following 340 equation 1. A sector was considered critical when CI was higher than 3.2 , as this value is 341 obtained exclusively by the combination of medium to very high indicators (Viavattene 342 et al., 2018). The CI values were, accordingly, classified into 5 categories (None or Very 
343 Low, Low, Medium, High and Very High) to allow a qualitative representation of the 344 hotspots along the area.

\section{RESULTS}

346 The results of the risk analysis are presented in the next sections. Flood and erosion risk 347 assessment are addressed separately, followed by an analysis of the interaction between 348 the two.

\subsection{Storm-induced flood risk assessment}

350 Table 4 shows the TWL for the 10- and 50-year return periods (T10 and T50, respectively) of the exposed sectors in the different municipalities of the study area. In exposed sectors, TWL varied from 2.3 to $6.6 \mathrm{~m}$ for T10 and from 2.5 to $7.2 \mathrm{~m}$ for T50. In semi-sheltered sectors, the TWL varied from 1.2 to $1.3 \mathrm{~m}$, considering both scenarios. The highest levels occurred in areas reached by higher wave energy and steeper beach slopes in Tijucas and Florianópolis (Table 4). It must be highlighted that Tijucas is, in fact, particularly susceptible to the occurrence of extensive flood episodes (Santos and Bonetti, 2018), since a relatively well-developed low-lying chenier coastal plain is established on its hinterland (FitzGerald et al., 2007).

Table 4. Computed values of TWL for exposed sectors in the different municipalities of Santa Catarina Central Coast

\begin{tabular}{|c|c|c|c|c|c|c|}
\hline \multirow{2}{*}{$\begin{array}{l}\text { Municipalities with } \\
\text { exposed sectors }\end{array}$} & \multicolumn{3}{|c|}{ TWL T10 } & \multicolumn{3}{|c|}{ TWL T50 } \\
\hline & $\max$ & $\min$ & mean & $\max$ & $\min$ & mean \\
\hline Tijucas & 6.6 & 4.9 & 5.7 & 7.2 & 5.4 & 6.3 \\
\hline Gov. Celso Ramos & 4.4 & 2.6 & 3.4 & 4.7 & 2.8 & 3.7 \\
\hline Florianópolis & 6.4 & 2.3 & 3.9 & 7.0 & 2.5 & 4.3 \\
\hline Palhoça & 4.4 & 2.3 & 3.4 & 4.8 & 2.5 & 3.7 \\
\hline Whole Central Coast & 6.6 & 2.3 & 3.9 & 7.2 & 2.5 & 4.2 \\
\hline
\end{tabular}

362 The flood hazard indicator in the T10 and T50 return periods is illustrated in Fig. 3A and 363 Fig. 4A, respectively. The results show that, considering the longer return period, the 364 hazard level in approximately 55\% of the sectors lies within classes 1 and 2. Still, the 365 classes of high and very high susceptibility (4 and 5) were representative, corresponding $36632.5 \%$ of the sectors for T50. In an analysis of the differences between the T10 and T50 scenarios, an increase in hotspots was observed in the most populated city, Florianópolis. 
368 The main flood-prone sectors, considering both scenarios, comprised the following 369 beaches (Fig. 3A and 4A): Tijucas, Palmas, Daniela, Canasvieiras, Cachoeira do Bom 370 Jesus, Ponta das Canas, Ingleses, Moçambique-Barra da Lagoa, Campeche, Armação and 371 Pinheira. Higher values of $i_{h}$ were concentrated in Tijucas and Florianópolis 372 municipalities: both sites included up to $78 \%$ of the most hazardous sectors (levels 4 and 373 5) in T50. Also, in this case, Gov. Celso Ramos was the municipality with lower $i_{h}$ values 374 (more than $73 \%$ of its total sectors belonged to the very low and low-level classes, 1 and 375 2).

376 The flood-related exposure indices are shown in Fig. 3B and 4B. The study area exhibits 377 large variability related to the degree of occupation (iexp_LU), with the very-high 378 exposure class (5) predominating, followed by the low and high categories (2 and 4). 379 Notably, most sectors that present very high levels of LU exposure are concentrated in 380 the Gov. Celso Ramos municipality and the north of Santa Catarina Island. High values 381 are mainly related to the presence of urban settlements close or very close to the shore.

382 The Social Vulnerability Indicator (iexp_VS) presented higher exposure rates in the 383 northern sectors of Tijucas, and east of Santa Catarina Island. The very-high exposure 384 class included the municipality of Tijucas and points located on Florianópolis beaches. 385 Notably, categories that contributed the most to the very high values were "per capita 386 income', 'vulnerable age group' and 'number of residents per household'. The high387 exposure class (4) predominated in Tijucas and Governador Celso Ramos municipalities. 388 In the T50 scenario, low to intermediate values characterized most of the stretches, 389 predominating the medium class (3) for approximately $35 \%$ of the sectors, followed by 390 the class of low social vulnerability (2), which represented $30 \%$.

391 Considering the transport system (Fig. 3B and 4B), the results showed that most of the 392 sectors presented very low exposure of their transport network: considering the longer 393 return period, only $13.2 \%$ were marked by very high exposure and were mainly 394 concentrated in the Florianópolis and Gov. Celso Ramos municipalities, which pointed 395 to a higher density of TS close to the shore in these locations. The predominance of very 396 low exposure in the area can be explained by the absence of infrastructure near the 397 shoreline. Still, it was possible to identify those areas where the transport system could 398 be affected. 


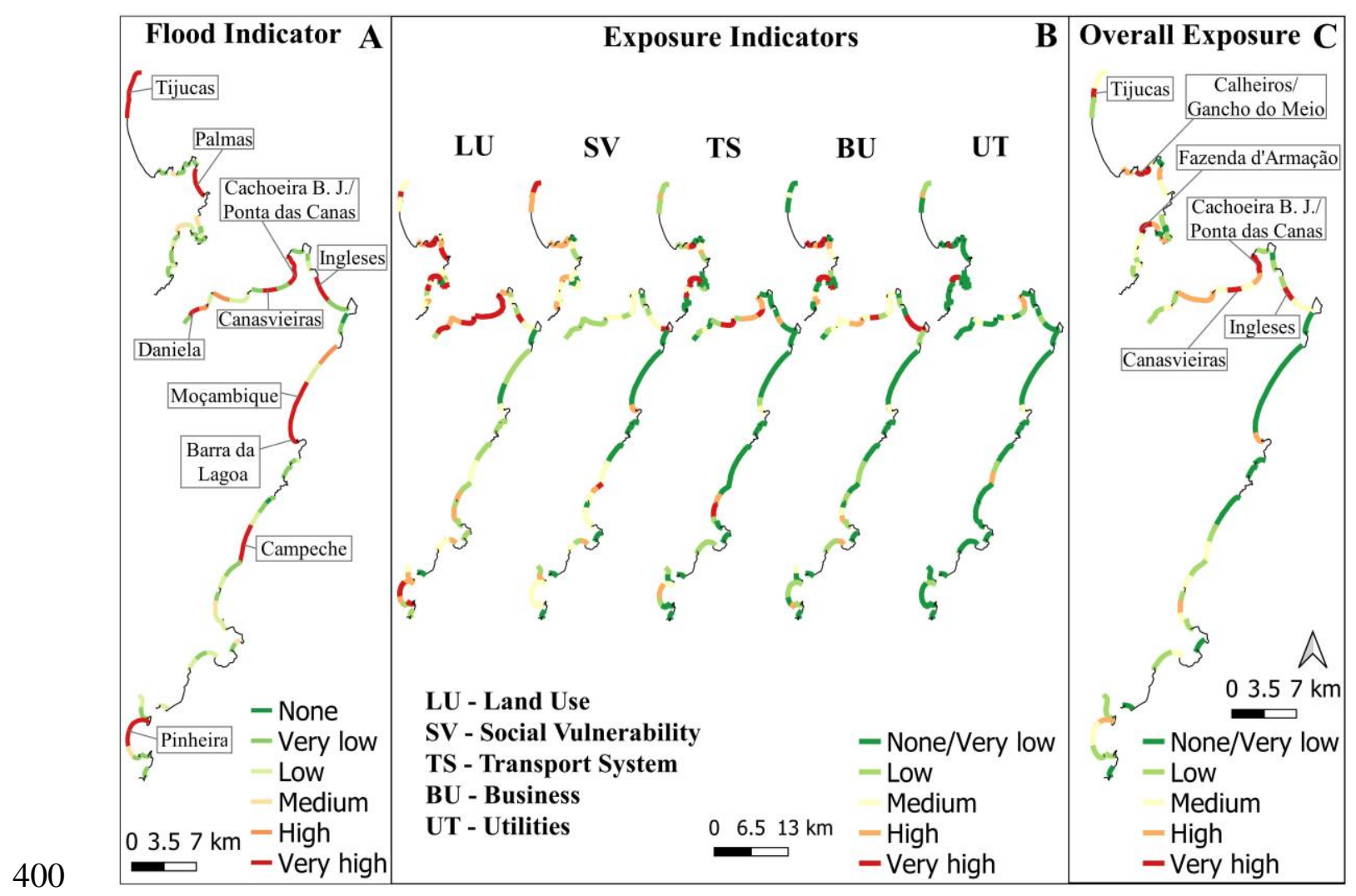

Fig. 3 (A) Flood impact and (B; C) exposure indicators for T10

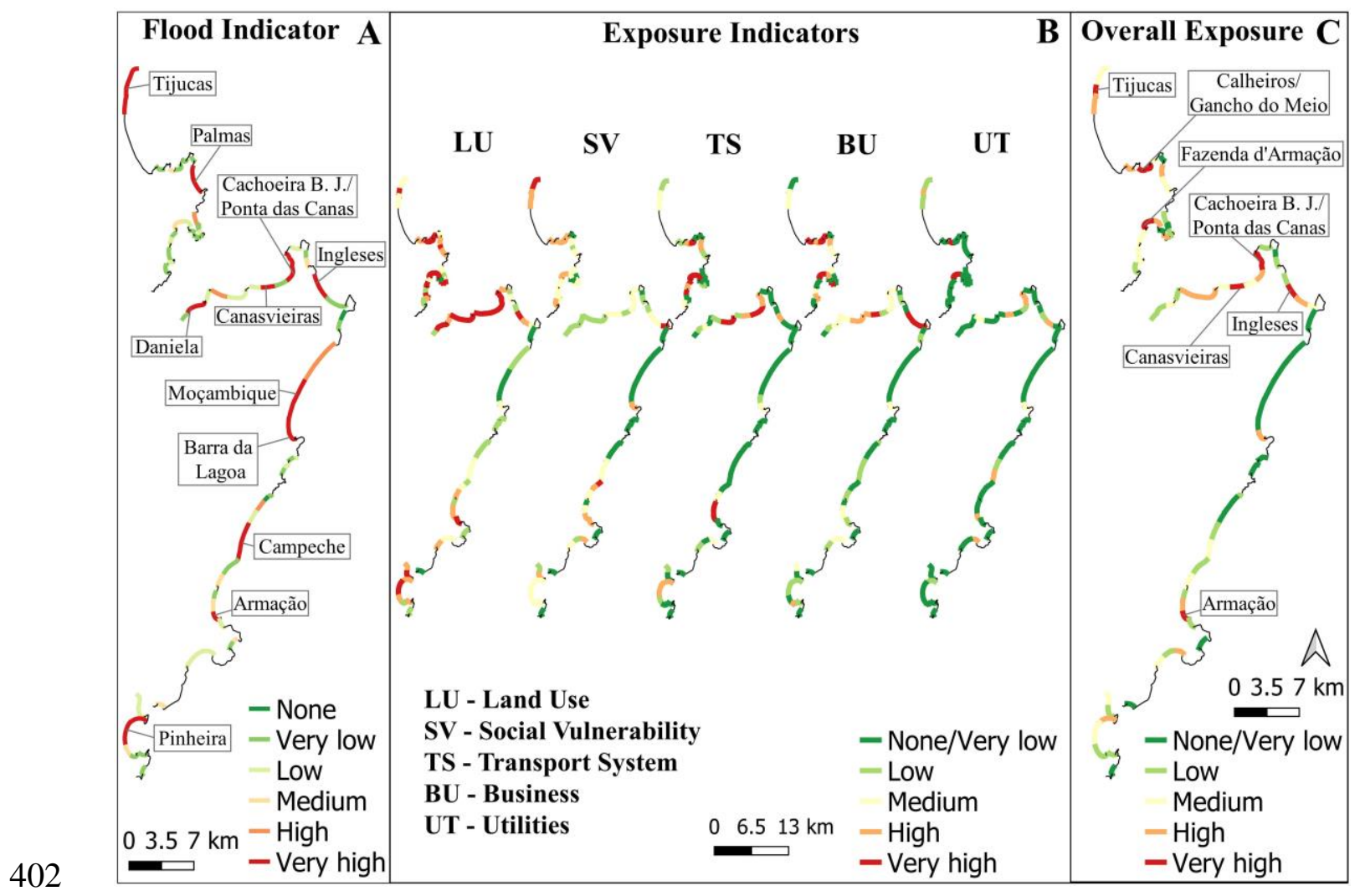


405 The Business indicator was mostly represented by units linked to commerce, followed by

406 entities related to the industry. Considering the T50 scenario, $10.8 \%$ of the sectors were 407 characterized by very high exposure (class 5), mostly in the municipality of Gov. Celso

408 Ramos, and the northern portion of Santa Catarina Island. Low and very low exposures 409 were dominant when considering both return periods, accounting for up to $60 \%$ of the 410 sectors.

411 The utility indicator was restricted in the study area: $80 \%$ of the sectors presented a very 412 low exposure class, considering the maximum hazard extent. This was also mainly due 413 to the absence of large infrastructure networks close to the shore. The very high exposure 414 class was concentrated exclusively in the municipality of Gov. Celso Ramos. High classes 415 (4) also appeared in the municipalities of Tijucas and Florianópolis. There was a 416 significant number of educational units close to the shore, which were mainly represented 417 by municipal elementary schools. Health units were rarer within the considered area and 418 were mostly represented by small medical centres.

419 The overall exposure index ( $\left.I_{\text {exp }}\right)$ is presented in Figs. 3C and 4C. Categories of Low and 420 Very Low exposure were predominant in the study area, covering up to $57 \%$ of the 421 sectors, highlighting that many of the exposure indicators used, especially those that were 422 linked to urban infrastructure exposure, are not highly represented close to the shore.

423 Nonetheless, eight sectors were considered extremely critical in the higher return period, 424 with high and very high classes of coastal exposure representing $20.4 \%$ of the total sectors 425 for T10 and $25.3 \%$ for T50. The extremely critical sectors included the following beaches 426 (Figs. 3C and 4C): Tijucas, Calheiros, Gancho do Meio, Fazenda d'Armação, 427 Canasvieiras, Ponta das Canas, Ingleses and Armação.

428 The municipalities of Tijucas and Governador Celso Ramos were predominantly 429 characterized by the medium exposure class; however, they had the highest percentages 430 of classes 4 and 5, when compared with other locations. The municipality of Florianópolis 431 presented a very heterogeneous distribution of exposure values, with the predominance 432 of very low and low exposure in both scenarios. Still, $22.4 \%$ of its sectors are represented 433 by classes 4 (high) and 5 (very high) in the T50 return period, which are concentrated 434 mainly on semi-sheltered locations at the north end of the Island. In the municipality of 
435 Palhoça, the low exposure class predominates, with only $12.5 \%$ of the sectors classified 436 as high exposure for both scenarios.

437 The results of the flood risk analysis are represented by the Coastal Index shown in Fig. 438 5. The computed indices varied from 0 to 5, and sectors with CI greater than 3.2 were 439 considered critical.

440

441

442

443

444

445

446

447

448

450

451

452

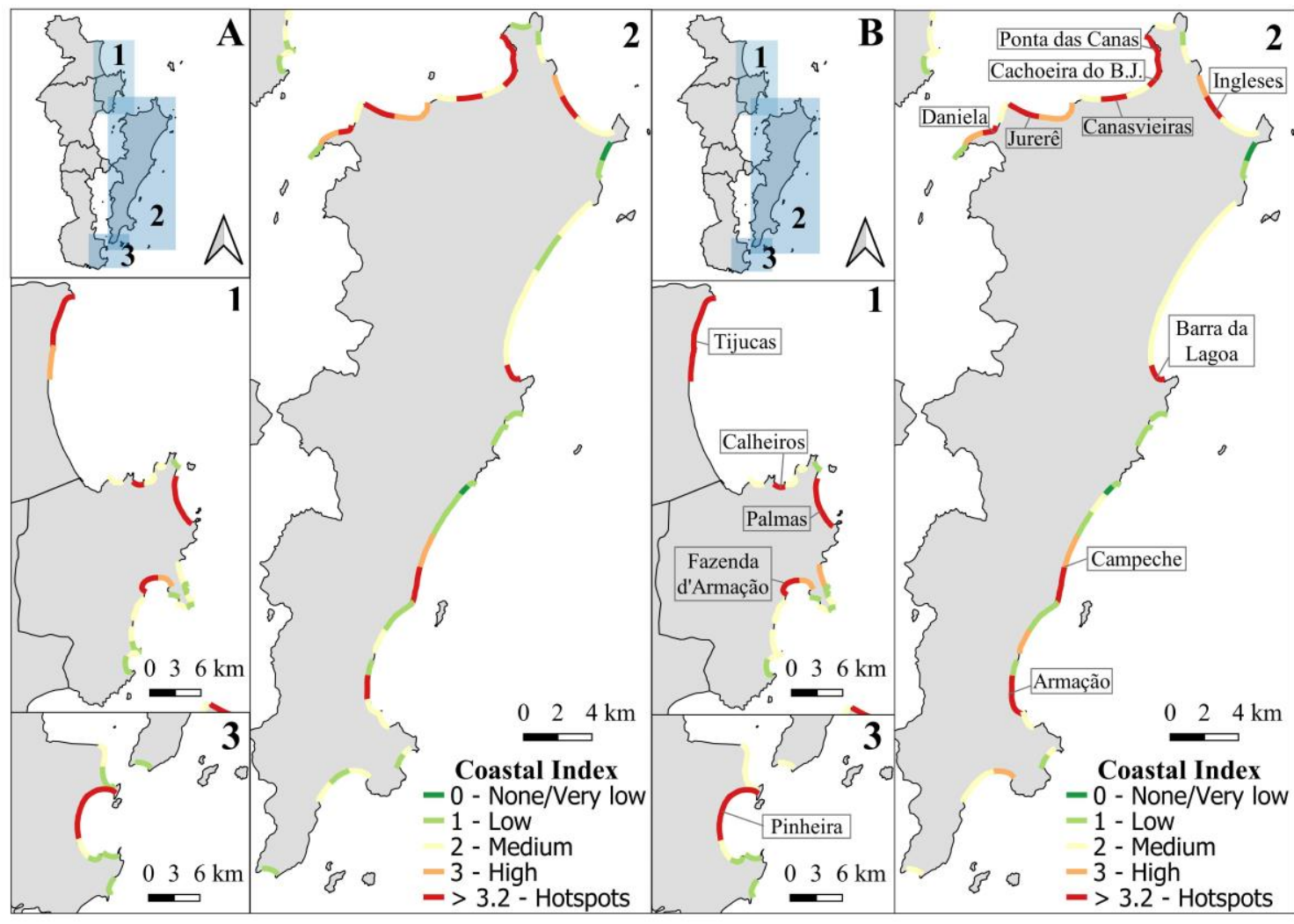

Fig. 5 Flood Coastal Index in T10 (A) and T50 (B) scenarios

The analysis identified 18 critical segments for T10 and 20 for T50, and the study area presented a CI average of up to 2.4. The segments considered to be at very high risk of flooding included the beaches of Tijucas, Palmas, Calheiros, Fazenda d'Armação, Daniela, Jurerê Internacional, Canasvieiras, Cachoeira do Bom Jesus, Ponta das Canas, Ingleses, Barra da Lagoa, Campeche, Armação and Pinheira (northern region) (Fig. 5).

It was observed that the critical sectors from exposed and semi-sheltered stretches presented different characteristics: the exposed ones were characterized by dune heights ranging from 0 to $2 \mathrm{~m}$, mostly with TWL values above the average $(4.2 \mathrm{~m})$ and short to medium beach width (22 $\mathrm{m}$ average), including consolidated and slightly urbanized shores. The semi-sheltered sectors presented lower TWL (usually lower than $1.3 \mathrm{~m}$ ); 
453 however, their backshore characteristics complicated the dissipation of storms. These 454 sectors presented higher exposure rates combined with a short beach width (13 $\mathrm{m}$ average) 455 and the absence of natural protection (dune height ranging from 0 to $1 \mathrm{~m}$ ). Moreover, the 456 semi-sheltered sectors characterized as critical included urbanized fringes.

457 The very-high-risk class represented $24 \%$ of the total sectors analysed in the longer return 458 period scenario. The municipality of Florianópolis showed the highest flooding risk for 459 both return periods, comprising up to $50 \%$ of the critical sectors. The municipality of 460 Tijucas also stood out for the concentration of extreme values with a CI average of up to 4614.4 and the totality of its sectors classified as very high-risk in T50 (see Fig. 5B). Low to 462 medium risk classes predominated in GCR and Palhoça.

463 In addition, there were no significant changes in critical sectors between T10 and T50: 464 the hotspots increased only on the Tijucas and Armação beaches. However, a 465 considerable number of segments showed an increase in the flood risk level to a high 466 flooding risk in the municipalities of Florianópolis and Governador Celso Ramos in the 467 longer return period scenario.

\subsection{Storm-induced erosion risk assessment}

469 Values of shoreline retreat varied from 0.12 to $4.87 \mathrm{~m}$ in the T10 scenario and from 12.76 470 to $206.8 \mathrm{~m}$ in the T50 scenario. The highest scores were found in the Florianópolis and 471 Tijucas municipalities, which also had the largest retraction average in the studied area 472 (Table 5).

Table 5. Computed values of shoreline retreat in the different municipalities of Santa Catarina Central Coast

\begin{tabular}{|c|c|c|c|c|c|c|}
\hline \multirow{2}{*}{$\begin{array}{l}\text { Municipalities with } \\
\text { exposed sectors }\end{array}$} & \multicolumn{3}{|c|}{ Rt T10 } & \multicolumn{3}{|c|}{ Rt T50 } \\
\hline & $\max$ & $\min$ & mean & $\max$ & $\min$ & mean \\
\hline Tijucas & 4.8 & 1.2 & 3.0 & 181.2 & 91.0 & 121.6 \\
\hline Gov. Celso Ramos & 0.7 & 0.2 & 0.4 & 67.5 & 26.3 & 45.2 \\
\hline Florianópolis & 3.4 & 0.1 & 1.0 & 206.8 & 12.7 & 72.5 \\
\hline Palhoça & 0.9 & 0.1 & 0.4 & 68.6 & 14.3 & 38.7 \\
\hline Whole Central Coast & 4.8 & 0.1 & 1.0 & 206.8 & 12.7 & 69.3 \\
\hline
\end{tabular}


476 The erosion indicator for the T10 and T50 return periods is illustrated in Fig. 6A and

477 7A. Under the T50 scenario, approximately $58 \%$ of the sectors presented null to low

478 hazards. Classes 4 and 5 represented $21.5 \%$ of the analysed sectors for T10 and $29.4 \%$

479 for T50.

480 The highlighted erosion-prone sectors comprised the following beaches: Tijucas, 481 Ingleses, Barra da Lagoa, Galheta, Joaquina, Campeche, Armação, Matadeiro and 482 Lagoinha do Leste (see Figs. 6A and 7A). The critical stretches were concentrated in the 483 municipalities of Tijucas and Florianópolis, indicating that these locations were more 484 susceptible to erosion. The least susceptible district was Palhoça, in which greater than $48575 \%$ of sectors had null and very low classes in both scenarios. Moreover, urban or 486 slightly urbanized coastal segments represented approximately $66 \%$ of the highest scoring 487 sectors in T50. Most of them were characterized by the absence of frontal dunes and 488 steeper beach face slopes.

489 Exposures to erosion impact are shown in Fig. 6B and 7B. The land use indicator was 490 mostly characterized by the medium class, which represented $43.1 \%$ of the analysed 491 sectors in the T50 scenario. The very high category represented up to $19.6 \%$ of the 492 analysed stretches and was concentrated in the municipalities of Governador Celso 493 Ramos and Florianópolis. Notably, the average beach width of these sectors was $16.5 \mathrm{~m}$, 494 with a predominantly absent dune class. High exposure values may be related to the 495 proximity of man-made infrastructure to the shore.

496 The very-_low-exposure class was predominant when assessing the Social Vulnerability 497 Indicator in both scenarios. The second most frequent class observed was the high498 exposure class, which represented $23.5 \%$ of the sectors in T50. The very-high-exposure 499 class was observed exclusively in the municipality of Tijucas and Florianopolis. Very 500 high exposure rates were specifically related to the 'per capita income' and the 'number 501 of residents per household'.

502 Infrastructure exposures (Transport System and Business) were the least representative 503 in the erosion impact extent. The transport network indicator is characterized by low 504 exposure in $47 \%$ of the sectors in the T50 scenario. The stretches that are represented by 505 very high exposure, are distributed along Florianópolis, Tijucas and Gov. Celso Ramos 506 municipalities. 


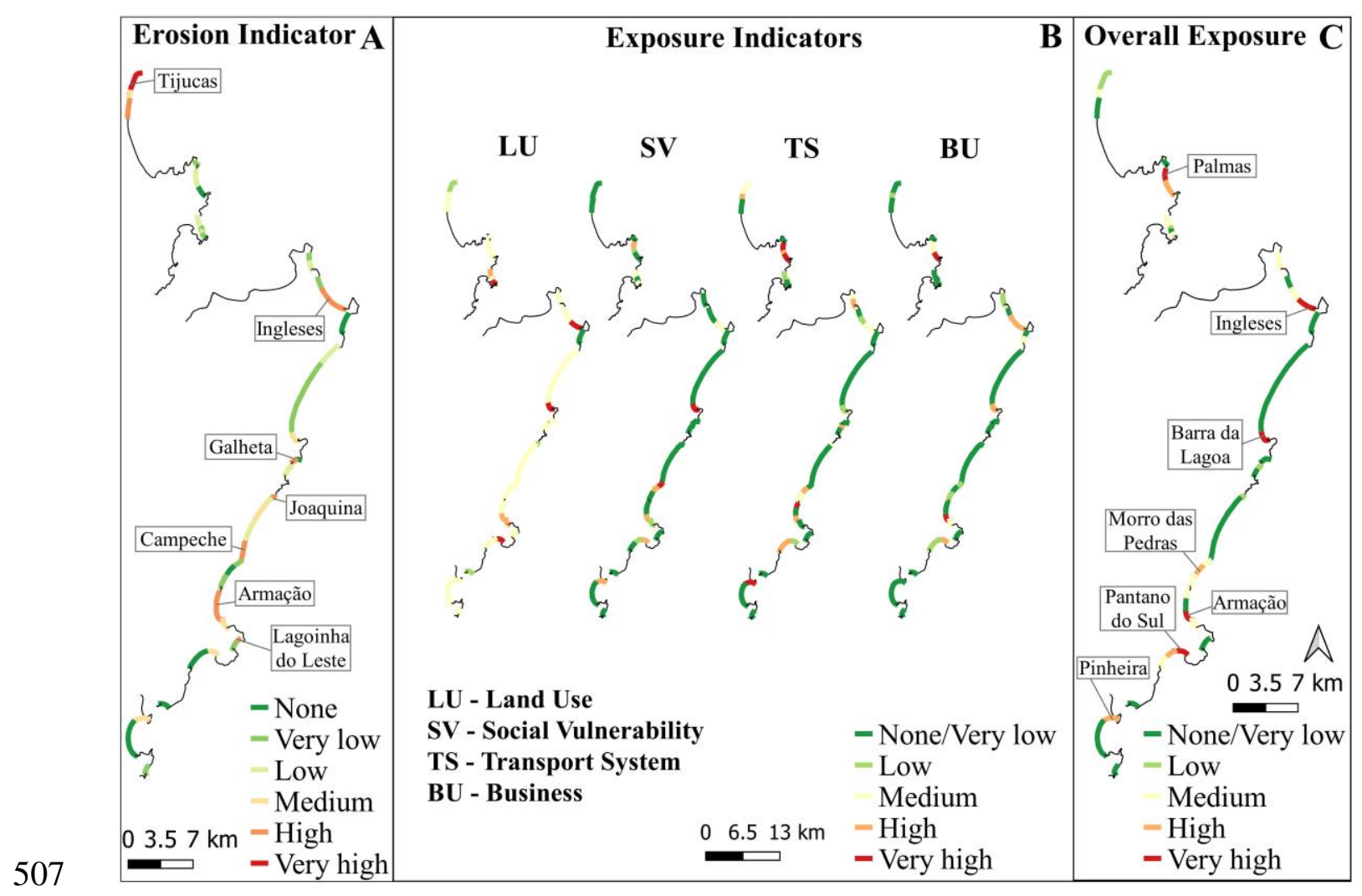

Fig. 6 (A) Erosion impact and (B; C) exposure indicators for T10

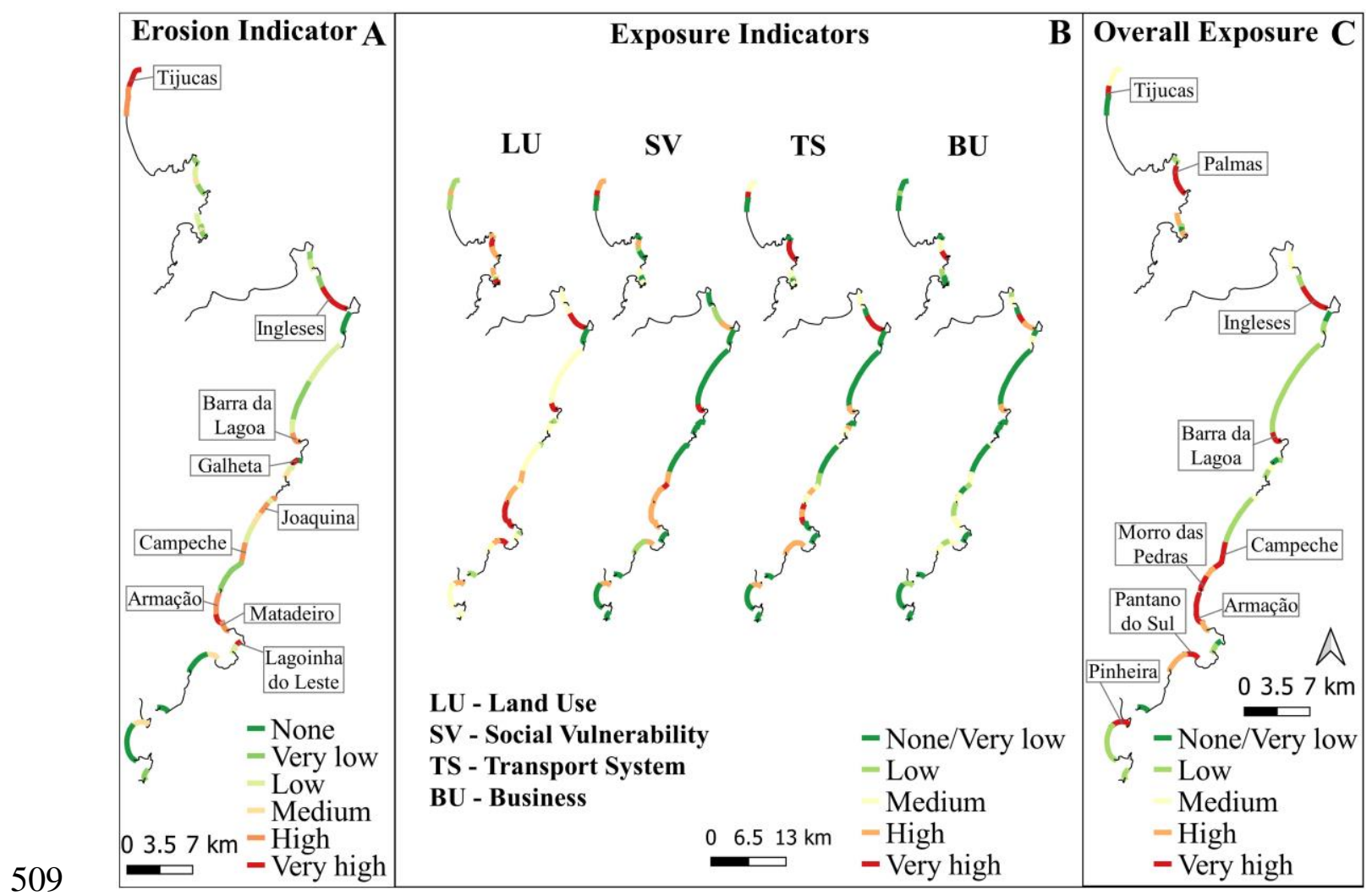

Fig. 7 (A) Erosion impact and (B; C) exposure indicators for T50 
511 The Business indicator was also mostly represented by very low exposure in both return

512 periods, T10 and T50. Up to $7.8 \%$ of the sectors are classified with high and very high

513 iexp_BU, which points to beaches in the municipalities of Florianópolis and Governador

514 Celso Ramos.

515 The overall exposure index $\left(I_{\text {exp }}\right)$ is shown in Figs. 6C and 7C. Among the exposed 516 sectors, the very low and low-exposure classes predominated in T10 and T50, 517 respectively. The high- and very-high-exposure classes represented $19.5 \%$ of the total 518 sectors for T10 and 41.1\% for T50. Florianópolis presented the highest exposure indices 519 to storm-induced erosion, comprising up to $66.6 \%$ of the sectors of high and very high 520 classes. This municipality was followed by Governador Celso Ramos, which was 521 characterized by beaches with reduced backshore at and a representative part of its 522 structures very close to the coastline. The following sectors were considered extremely 523 critical in exposures terms: Tijucas, Palmas, Ingleses, Barra da Lagoa, Campeche, Morro 524 das Pedras, Armação, Pântano do Sul and Pinheira (Ponta do Papagaio) (see Figs. 6C and 525 7C).

526 The results of erosion risk analysis are represented by Fig. 8 for both scenarios. In the 527 study area, sectors with medium risk (category 3) for return periods T10 and T50 528 predominated, with a CI average of up to 2.3. The very high class represents 529 approximately $27 \%$ of the exposed segments in the T50 scenario. Moreover, among 51 530 sectors, only eight sectors show null erosion risk and are concentrated in the municipalities of Florianópolis and Palhoça (see Fig. 8B).

532 The analysis identified seven critical sectors for the T10 and 14 for the T50, 533 corresponding, respectively to $13.7 \%$ and $27.4 \%$ of the stretches at very high erosion risk 534 in the SC-CC. The hotspots were specifically located on the following beaches (Fig. 8B):

535 Tijucas, Palmas, Ingleses, Barra da Lagoa, Joaquina, Campeche, Armação, Matadeiro, 536 Pantano do Sul and Pinheira (Ponta do Papagaio). There was a large increase of critical 537 sectors for T50 and the highlighted changes were mainly represented in the municipalities 538 of Tijucas and Florianópolis. The high CI rates were driven by high values of exposure 539 indicators, such as land use and transport systems, combined with medium to high values 540 of hazard indicators. Morphologically, the critical sectors are mostly characterized by the 541 absence of frontal dunes (78\%) and a short beach width (average: $20 \mathrm{~m}$ ). As expected, 542 most of them are localized on Santa Catarina Island (71\% in the higher return period 543 scenario), which present geographically higher exposure to hydro-meteorological events 


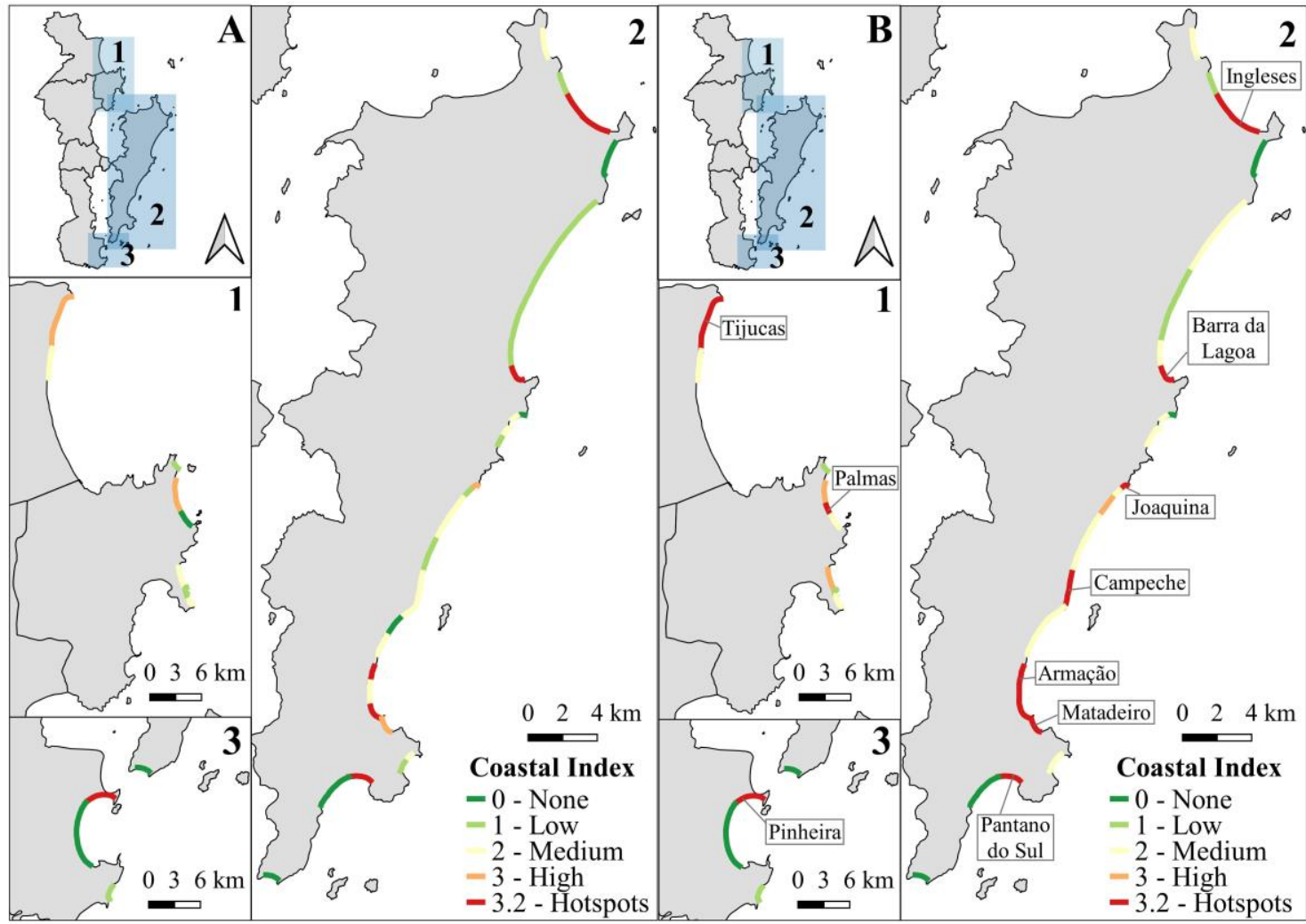

Fig. 8 Erosion Coastal Index in T10 (A) and T50 (B) scenarios

and an important urban development near the coast.

548 The results indicate that Florianópolis is the most susceptible and vulnerable municipality to the hazard of erosion in the study area. Considering the longer return period, middle and very high risk predominates $(72 \%)$ in this city. Tijucas presents the second highest risk of erosion. With a CI average of 3.4, the risk varies from medium to very high. In the municipality of Gov. Celso Ramos, the low and medium classes predominate, while Palhoça is mainly represented by the null to low-risk categories.

\subsection{Critical areas for erosion and flooding hazards}

556 In the area, the hotspots that included simultaneously erosion and flooding hazards in the 557 longer return period scenario were Tijucas, Palmas, Ingleses, Barra da Lagoa, Campeche, 558 Armação and Pinheira (see Fig. 9). The highest CI values were found in the municipalities 559 of Florianópolis and Tijucas, suggesting that they are the most susceptible and vulnerable 560 sectors to storm-induced impacts. 


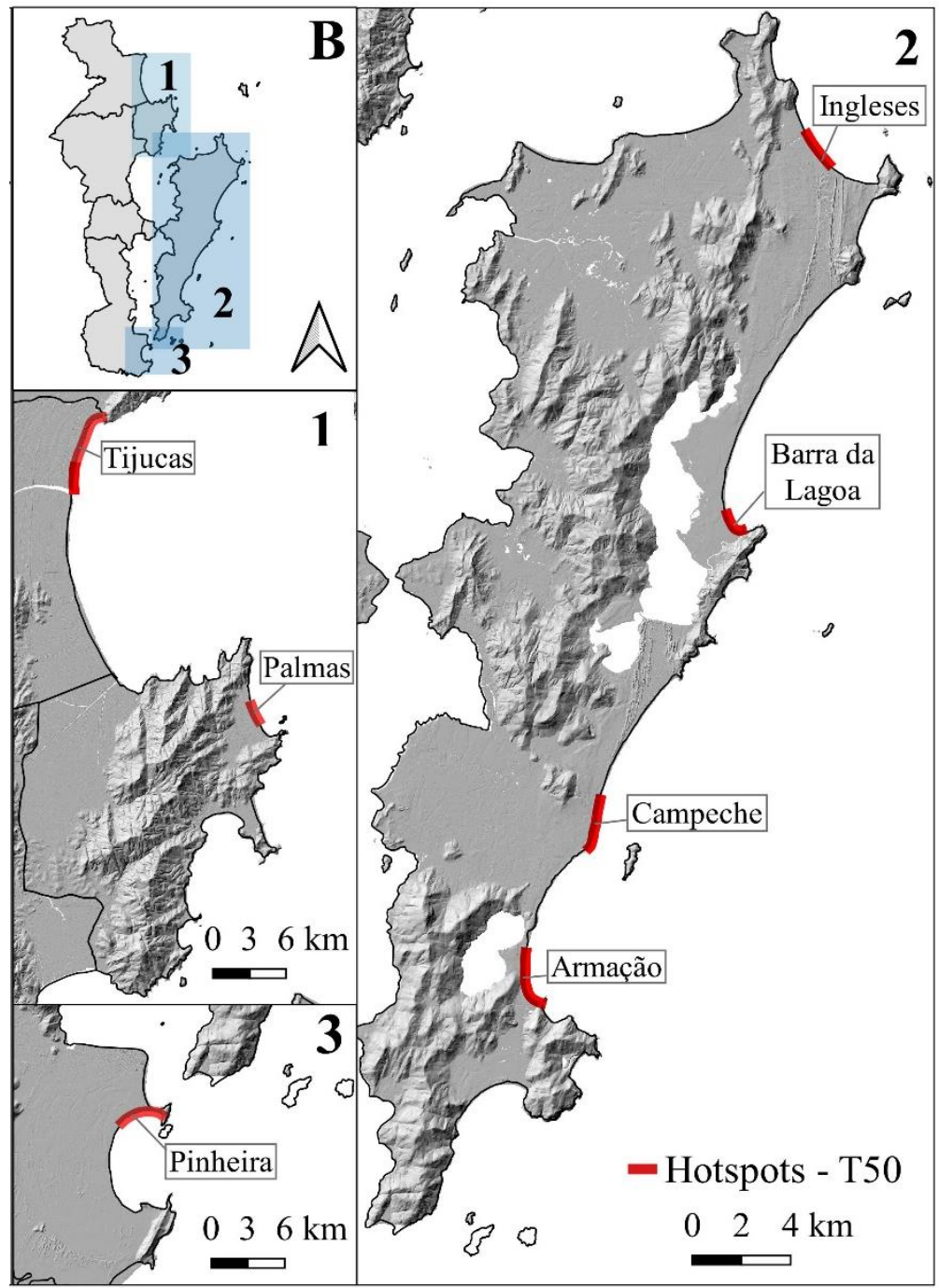

562 Fig. 1 Hotspots that may be submitted simultaneously to very high erosion and flooding hazard impacts in the longer return period scenario (50 years).

\section{DISCUSSION}

566 Integration of existing data, empirical models and spatial analysis allowed us to perform

567 a flood and erosion risk assessment, which provided additional information concerning 568 the area of interest. The chosen approach proved to be efficiently adaptable to data-poor areas, especially the hazard assessment module of the framework.

570 The high flood CI rates essentially reflected the rank of the flood impact indicators and

571 the spatial distribution of specific exposure descriptors, such as land use and transport systems.

573 The higher values of the flood impact indicators can be justified by the interaction between the morphological and hydrodynamic characteristics of each sector: in general, 
575 these segments are exposed to a higher incidence of waves, with poorly developed or non-

576 existent dunes and TWL values above the average calculated for the whole area (4.2 $\mathrm{m})$.

577 Thus, the distribution of critical sectors is mainly controlled by their geographic position,

578 geological heritage and/or by changes linked to anthropic interference that usually is

579 related to the removal of natural barriers (e.g. primary foredune), favouring hinterland

580 exposure.

581 On the other hand, the degrees of exposure reflect the distinct patterns of urbanization

582 and socio-economic activity in the different municipalities. Governador Celso Ramos and

583 Florianópolis show a higher density of urban industries and infrastructure networks close

584 to the shore, which is why a greater number of elements are exposed to the scenario

585 proposed here. In the case of Tijucas, the most exposed sectors are essentially linked to

586 the social vulnerability index, since it has a low-income population settled near the

587 coastline, which is an exception in the area.

588 Some identified hotspots, such as the beaches of Barra da Lagoa and Armação in the 589 municipality of Florianópolis (see Fig. 5B), have been highlighted previously to be under

590 flooding and erosion threat (Bonetti et al., 2013; Klein et al., 2016b). Other examples are

591 the beaches of Canasvieiras, Ponta das Canas, Ingleses and Campeche, which were among

592 the most affected areas during the storms observed from 1991 to 2001 (Simó and Horn

593 Filho, 2004). A study carried out on a smaller scale by Klein et al. (2016a) also points to

594 the Barra da Lagoa and Ingleses beaches under a flood regime and to Ponta das Canas,

595 Canasvieiras, Jurerê and Daniela under an overwash regime for T50 (according to the

596 scale of flooding regime proposed by Sallenger, 2000).

597 Considering the analysis of the distinct probabilistic distribution, there were no major 598 changes between scenarios. As the hazard extent was probably limited by the 599 morphological characteristics in the study area, the exposures presented a slight increase 600 in the higher values as well.

601 The superior CI rates presented in the erosion risk assessment were mostly driven by high 602 values of exposure indicators combined with medium to high hazard categories. The 603 exposure assessment reflected essentially the land use and the transport system 604 descriptors, as did the flood exposure analysis. Concerning the erosion assessment, it was 605 observed that very high retraction rates were related to very low dune height classes and 
606 short beach widths. The variables used to characterize beach morphology had the greatest

607 influence on the results, showing the importance of using higher resolution topographic

608 and bathymetric data to apply this approach. However, it can be noticed that the results

609 of the hazard assessment followed the general pattern of the study area, with a retraction

610 average for the whole area of $69.3 \mathrm{~m}$ for the T50 return period (Table 5). A similar value

611 was found by Mazzer and Dillenburg (2009), which presented an average retreat of up to

$61270 \mathrm{~m}$ for some sectors in the southeast of Santa Catarina Island in a period of 64 years.

613 The higher risk values highlight some of the exposed beaches that have historically 614 greater erosion problems: some critical sectors in Florianópolis, such as Ingleses, Barra 615 da Lagoa, Joaquina, Campeche, Armação, Matadeiro and Pantano do Sul (see Fig. 8B), 616 are well known areas where erosive process linked to different causes have already been 617 described (Abreu de Castilhos et al., 1995; Castilhos and Gré, 1997; Torronteguy, 2002; 618 Simó and Horn Filho, 2004; Faraco et al., 2006; Mazzer et al., 2008; Oliveira et al., 2008; 619 Mazzer and Dillenburg, 2009; Rudorff and Bonetti, 2010; Bonetti et al., 2013; Klein et 620 al., 2016b; Dalbosco et al., 2019; Leal et al., 2020)

621 Bonetti et al. (2018) assessed the susceptibility of sandy beaches to erosion for the entire Santa Catarina coast. The authors primarily considered environmental indicators in the analysis; thus, some results are similar to the observed pattern presented here for the erosion hazard assessment. The study pointed to the dominance of low- to mediumsusceptibility values in the south sector of the state, whereas an alternated distribution of susceptibility classes, tending to higher values, prevails in the Santa Catarina Island (Florianópolis). However, differences can be seen especially in the exposed beaches of Gov. Celso Ramos and Tijucas municipalities, and they can be explained by the influence of the hydro-meteorological components on the hazard assessment. Along the Santa

630 Catarina Coast, the inclusion of wave data has already been pointed out for having a large 631 impact on the final result of susceptibility/vulnerability assessment (Serafim et al., 2019). 632 Nevertheless, the primary control of the geological setting, beach orientation and 633 proximity of man-made infrastructure over the vulnerability of the Santa Catarina coast, 634 as previously proposed by Bonetti et al. (2018), was confirmed in our study.

635 The analysis of the T10 and T50 scenarios shows that the level of erosion risk tends to 636 increase in the study area when considering a higher return period and suggests that the 637 Santa Catarina Coast will be largely affected by coastal retreat. Furthermore, considering 
638 both hazards, the scenario tends to worsen due to the interactive relationship between the

639 two process and the human activities on the coastal plain (Pollard et al., 2018).

640 In summary, the regional pattern identified for flooding and erosion risk is corroborated

641 by the historical analysis based on the state's Civil Defence disaster databank, presented

642 by Rudorff et al. (2014): Florianópolis is the most affected municipality in Santa Catarina

643 State, and the other municipalities in the central sector, excepted Tijucas, have no record

644 of emergency situations linked to storm induced-waves and surges. The authors attributed

645 this fact to the presence of the island, which acts as a natural barrier to large wave systems,

646 partially protecting the adjacent coast.

647 Tijucas is historically characterized by a low frequency of damages related to storm

648 surges. Its coastline is located at the inner portion of a sheltered bay where wave energy

649 is attenuated by the process of refraction and diffraction due to its morphological

650 configuration and muddy inner shelf substrate. However, high susceptibility levels to

651 extreme events, particularly flood, have been reported on a local scale (Santos and

652 Bonetti, 2018). These events are concentrated in a sector where a long-term retreat of the

653 coastline was detected by these authors based on the analysis of historical images and can

654 be explained by the presence of low-lying areas and their greater exposure to the east 655 waves.

656 The results are also partially corroborated, in a comparative way, with the analysis

657 developed on regional scale by Serafim et al. (2019). The study highlights most of the

658 sectors presented here as at high risk for both hazards (Fig. 9) (assigns high and very high

659 scores to Palmas, Barra da Lagoa, Armação, Campeche and Pinheira beaches) and points

660 out that most of the critical stretches are related to the low adaptive capacity found in

661 areas with high occupational density. Similarly, here the critical sectors are driven by the

662 high exposure indices (in turn related to high occupational density) but also by the

663 morphological configuration, which controls the segment susceptibility to the main wave

664 direction (as also suggested by Bonetti et al., 2018 and Mussi et al., 2018, using different

665 scales).

666 The role of the morphological configuration was also discussed by Muler and Bonetti 667 (2014), who presented a vulnerability analysis for Santa Catarina Island based on different 668 wave directions. The study showed that, although south and southeast waves present the 
greatest heights, they are associated with low exposure of buildings because most of the populated sectors are located on semi-sheltered portions of the Island.

671 The results also highlight the key role that dunes may play in coastal protection. Dune absence or fragmentation has been related to the very high impacts of flood and erosion.

673 In the study area, human occupation takes place over the Holocene coastal plain, 674 represented by unconsolidated sandy sediments that offer even less protection to storm 675 wave action. Anthropic activities in these areas contribute to the intensification of erosive 676 processes because of the imbalance in the sediment budget of the coast, which sometimes 677 lead to the decrease of the beach extent and presence of natural barriers, consequently 678 making the hinterland more vulnerable to the flood events. For example, in Ingleses beach there is a natural input of sand from two dune fields that bring sediments from Santinho and Moçambique beaches (through sand overpassing). In the last decades, urban development in this sector was established over the dunes, interrupting sand transport and leading to a local deficit of sediments (Vieira da Silva et al., 2016).

683 It is important to notice that, although the erosion assessment was carried out only for the 684 exposed sectors, many semi-sheltered beaches are characterized by low-land areas and 685 presented an extremely low level of protection in face of a small TWL increase. Studies 686 carried out in the Florianópolis region show that even considering only the sea level rise, 687 the city has little or no protection from its effects (Montanari et al., 2020). Furthermore, for sheltered and semi-sheltered sectors, the regional pattern of beach responses to extreme events can be disrupted on a local scale due to the connectivity between beach systems via physical processes, like sediment redistribution or/and headland bypassing

691 (Burvingt et al., 2017).

692 Even though the need to apply some alternatives for the treatment of the predicted 693 variables in CRAF1, the tool proved to be flexible enough to be used in conditions of 694 greater data scarcity. It has already been pointed out that, specifically for hazard assessment, the type of data required make it difficult to evaluate some coastal stretches at regional levels (Narra et al., 2019); however, in this study, we show that the tool can

697 be implemented with simplifications by using some alternatives. Here, several parameters 698 were simplified due to the low resolution of the input data; nevertheless, the general 699 pattern was respected, corroborating the well-known areas and providing important 700 information, especially in qualitative terms, for the Santa Catarina Central Coast. 
702 This study applied the CRAF1 framework in a data-scarcity condition, focusing on the 703 Santa Catarina Central Coast, to identify storm-induced hotspots of flood and erosion. 704 The approach proved to be efficient and adaptable to sites where high-resolution data are 705 usually unavailable. Despite the need to adopt some assumptions and simplifications, the 706 method generated useful results for the identification of critical risk areas.

707 The flood and erosion hazards were estimated according to TWL and coastline retraction 708 for T10 and T50. In the longer return period scenario, TWL pointed to an average of 4.2 $709 \mathrm{~m}$ in the study area, making several sectors susceptible to damage, especially those that 710 suffer with great wave energy action and present high values of beach face slope, such as 711 Tijucas and Florianópolis. In addition, the storm-induced retreat indicated expressive 712 shoreline displacement for several sectors, highlighting some of the exposed beaches that 713 have historically greater erosion problems, such as Ingleses and Armação on Santa 714 Catarina Island.

715 The hazard indicators stressed some of the well-known areas prone to the impacts of 716 flooding and erosion. The municipalities that concentrate the most hazardous classes are 717 Tijucas and Florianópolis. The highest scores are related to the presence of low-land areas 718 combined with insignificant values of frontal dune heights, which make the environment 719 more susceptible even in semi-sheltered sectors.

720 The exposure analysis was carried out taking into account the presence of different 721 receptors within the delineated impact extent. The general exposure indicator showed that 722 categories of low and very low exposure are predominant. Those of very high exposure 723 are the least frequent and characterize the municipalities of Tijucas and Governador Celso

724 Ramos for the impact of flooding and Florianópolis and Governador Celso Ramos for the 725 impact of erosion. Three sectors comprising the beaches of Tijucas, Ingleses and Armação showed the highest exposure rates for both hazards. Moreover, the upper index values

727 allowed us to determine how the exposure of a particular receptor influenced the general 728 exposure indicator: the variables with the greatest influence on exposure levels were land 729 use and transport system categories. Utilities was the less expressive descriptor in the 730 area.

731 The integration of indicators through risk maps allowed the identification of 18 critical 732 segments for T10 and 20 for T50 concerning flood risk. Likewise, in respect to erosion 
733 risk, where the analysed area corresponds to the exposed sectors to the main wave 734 directions, seven critical stretches were identified for T10 and 14 for T50. In both cases, 735 the sectors under very high risk to storm-induced impacts include the municipalities of 736 Florianópolis and Tijucas, which correspond to the areas with the highest number of 737 registered warning recurrences due to storm events. Among the exposed sectors, nine 738 simultaneously presented the risk of erosion and flooding in the longer return period 739 scenario. This result was related to the anthropic occupation of lowland areas, which are 740 naturally more susceptible to wave impacts.

741 The risk analysis in probabilistic terms allowed the identification of the main hazard in 742 the study area, showing that the storm-induced erosion process tended to be more severe 743 along the years when compared with the flooding process. However, often these hazards 744 are strongly related, and when considering a large return period, a major impact can reach 745 a greater number of stretches, as the hinterland becomes more susceptible.

746 Some simplifications were necessary when applying the methodology, for example, to 747 obtain geomorphological and hydraulic parameters, as well for the data used in the 748 exposure analysis. The risk assessment also took into account the maximum hazard extent 749 in each sector and did not consider important parameters related to overwashing 750 processes, obstacles, soil infiltration and the presence of river basins, which may 751 influence the regional vulnerability pattern.

752 Nevertheless, it was possible to identify the most critical areas, which coincide with those 753 where damage was registered during extreme events and also with some hotspots 754 highlighted in previous works. Although many previous studies have been developed in 755 the area, future sea-level rise scenarios were not considered in those analyses, a factor 756 that can be of great importance for management purposes. In this way, the results obtained 757 here can be used as the basis for future research by indicating the areas that deserve more attention and more detailed analysis in the perspective of potential risk.

759 This study proposed some alternatives that allow the implementation of the CRAF1 tool 760 conditions of data scarcity. With this, it is expected to inspire similar analyses in countries 761 that do not have a structured spatial data infrastructure, expanding the scope of the 762 original methodology applied in Europe. 


\section{ACKNOWLEDGMENTS}

766 This work was supported by the Research and Innovation Support Foundation of Santa

767 Catarina State (FAPESC) through project number 23038.013359/2017-71 in the

768 framework of the Master in Oceanography Programme at the Federal University of Santa

769 Catarina (UFSC). JB is a Research Fellow of the Brazilian Conselho Nacional de

770 Desenvolvimento Científico e Tecnológico (CNPq; Grant 306633/2019-1), and his

771 participation in this study was partially granted by the Coordenação de Aperfeiçoamento

772 de Pessoal de Nível Superior, Brazil (CAPES; Process 8881.337427/2019).

773

774

775

776

777

778

779

780

781

782

783

784

785

786

787

788

789

790

791

792

793

794

795

796

797

798 


\section{REFERENCES}

800

801

802

803

804

805

806

807

808

809

810

811

812

813

814

815

816

817

818

819

820

821

822

823

824

825

826

827

828

829

830

831

832

833

834

835

836

837

838

839

Abreu de Castilhos J, Klingebiel A, Gré JCR (1995) Les plages de l'ile de Santa Catarina (Brèsil): un systéme sèdimentaire évolutif et précaire. In: Conference on Coastal Change. IOC/UNESCO, Bordeaux.

Araujo CES, Franco D, Melo Filho E, Pimenta F (2003) Wave regime characteristics of southern Brazilian coast. Paper presented at International Conference on Coastal and Port Engineering in Developing Countries COPEDEC VI, 15-19 September, Colombo, Sri Lanka.

Armaroli C, Duo E, (2018) Validation of the coastal storm risk assessment framework along the Emilia-Romagna coast. Coast Eng 134:159-167 https://doi.org/10.1016/j.coastaleng.2017.08.014

Aucelli PPC, Di Paola G, Rizzo A, Rosskopf CM (2018) Present day and future scenarios of coastal erosion and flooding processes along the Italian Adriatic coast: the case of Molise region. Environ Earth Sci 77:371. https://doi.org/10.1007/s12665-018$7535-\mathrm{y}$

Bonetti J, Woodroffe CD (2017) Spatial Analysis on GIS for Coastal Vulnerability Assessment. In: Bartlett D, Celliers L (eds) Geoinformatics for Marine and Coastal Management. CRC Press, Boca Raton, pp 367-396 https://doi.org/10.1201/9781315181523-17

Bonetti J, Klein AH, Muler M, Luca C, Da Silva G, González M (2013). Spatial and numerical methodologies on coastal erosion and flooding risk assessment. In: Finkl, C. (ed) Coastal Hazards. Coastal Research Library Series. Springer, Dordrecht, pp 423-442. https://doi.org/10.1007/978-94-007-5234-4_16

Bonetti J, Rudorff F, de M, Campos AV, Serafim MB (2018) Geoindicator-based assessment of Santa Catarina (Brazil) sandy beaches susceptibility to erosion. Ocean Coast Manag 156:198-208. https://doi.org/10.1016/j.ocecoaman.2017.08.009

Bruun P (1954) Coast erosion and the development of beach profiles. Technical Memorandum. Beach Eros. Board, Corps Eng 44:82.

Burvingt O, Masselink G, Russell P, Scott T (2017) Classification of beach response to $\begin{array}{lll}\text { extreme } & \text { storms. } & \text { Geomorphology }\end{array}$ https://doi.org/10.1016/j.geomorph.2017.07.022

Castilhos A de J, Gré JCR (1997) Praias da ilha de Santa Catarina: caracterização morfológica e problemas de erosão costeira, in: Sierra de Ledo, B., Klingebiel, A., Soriano-Sierra, E. (Eds) Atas, Colóquio Franco-Brasileiro - Manejo Costeiro Da Ilha de Santa Catarina. Universidade Federal de Santa Catarina, Florianópolis pp $107-113$

CEPAL (2012) Efectos del cambio climático en la costa de América Latina y el Caribe: riesgos. Organización de las Naciones Unidas, Comisión Económica para América Latina y el Caribe, Santiago, Chile, p 118

Christie EK, Spencer T, Owen D, McIvor AL, Möller I, Viavattene C (2018) Regional coastal flood risk assessment for a tidally dominant, natural coastal setting: North 
Church JA, White NJ, Aarup T, Wilson WS, Woodworth PL, Domingues CM, Hunter JR, Lambeck K (2008). Understanding global sea levels: past, present and future. In: Sustainability Science pp 9-22. https://doi.org/10.1007/s11625-008-0042-4

CNES (2018). Cadastro nacional de estabelecimentos de saúde [www document]. URL http://cnes.datasus.gov.br/pages/estabelecimentos/extracao.jsp. (accessed 8.20.11).

Dalbosco ALP, Barletta R do C, Franco D (2019) Relação entre as variações da linha de costa e as características morfodinâmicas da praia da Armação, ilha de Santa Catarina. Geociências (São Paulo) 38:241-256.

Dalinghaus C, Schweitzer A, Hernadez AO, Da Silva GV, Oliveira JG, Da Silva PG, Ribeiro PJC, Araújo RS, Klein AHF (2015) Diferentes abordagens metodológicas para análise das consequências de marés de tempestade: ambientes praiais antropizados e naturais. pp 21-64

Dean RG (1977) Equilibrium beach profiles: U.S. Atlantic and Gulf coasts. Department of Civil Engineering, Ocean Engineering Report No. 12, University of Delaware. Newark, Delaware.

Dean RG (1987) Coastal sediment processes: toward - engineering solutions. In: Coastal Sediments. American Society of Civil Engineers. pp 1-24

De Angeli S, D'Andrea M, Cazzola G, Dolia D, Duo E, Rebora N (2018) Coastal Risk Assessment Framework: Comparison of modelled fluvial and marine inundation impacts, Bocca di Magra, Ligurian coast, Italy. Coast Eng 134:229-240 https://doi.org/https://doi.org/10.1016/j.coastaleng.2017.09.011

DEINFRA, 2018. Departamento estadual de infraestrutura [www document]. Download mapa rodoviário. URL http://www.deinfra.sc.gov.br/maparodoviario (accessed 8.20.11).

Faraco KR, Castilhos JA, de Filho NOH (2006) Morphodynamic aspects and El Niño oscillations in Ingleses beach, Santa Catarina island, southern Brazil. J Coast Res https://doi.org/10.2307/25741658

FitzGerald DM, Cleary WJ, Buynevich IV, Hein CJ, Klein AHF, Asp N, Angulo R (2007) Strandplain evolution along the southern coast of Santa Catarina, Brazil, Journal of Coastal Research, SI 50, p 152-156

Hallermeier RJ (1978) Uses for a calculated limit depth to beach erosion. In: Coastal Engineering 1978. American Society of Civil Engineers, New York, NY, pp 14931512. https://doi.org/10.1061/9780872621909.090

Hanson S, Nicholls R, Ranger N, Hallegatte S, Corfee-Morlot J, Herweijer C, Chateau J, Hanson S, Nicholls R, Ranger N, Hallegatte S, Corfee-Morlot J (2011) A global ranking of port cities with high exposure to climate extremes. Clim Change 104:89111. https://doi.org/10.1007/s10584-010-9977-4

Holman RA (1986) Extreme value statistics for wave run-up on a natural beach. Coast Eng 9:527-544. https://doi.org/10.1016/0378-3839(86)90002-5

Horn Filho NO (2006) Ilha de Santa Catarina, in: Muehe D (Ed) erosão e progradação do 
litoral brasileiro: ministério do meio ambiente. Ministério do Meio Ambiente, Brasília, pp 413-436

IBGE - Instituto brasileiro de geografia e estatística (2011) Base de informações do Censo Demográfico 2010: resultados do universo por setor censitário.

IH-Cantabria (2013) IH-AMEVA: Análisis matemático y estadístico de variables medio ambientales. Instituto de Hidráulica Ambiental Universidad de Cantabria.

Jenks GF, Caspall FC (1971) Error on choroplethic maps:definition, measurement, reduction. Annals of the Association of American Geographers 61:217-244

Jiménez JA, Sanuy M, Ballesteros C, Valdemoro HI (2018) The Tordera Delta, a hotspot to storm impacts in the coast northwards of Barcelona (NW Mediterranean). Coast Eng 134:148-158. https://doi.org/https://doi.org/10.1016/j.coastaleng.2017.08.012

Kirezci E, Young IR, Ranasinghe R, Muis S, Nicholls RJ, Lincke D, Hinkel J (2020) Projections of global-scale extreme sea levels and resulting episodic coastal flooding over the 21st Century. Sci Rep 10:11629. https://doi.org/10.1038/s41598-02067736-6

Klein AHF, Prado MFV, Dalinghaus C, De Camargo JM (2016a) Metodologia para quantificação de perigos costeiros e projeção de linhas de costa futuras como subsídio para estudos de adaptação das zonas costeiras: litoral norte da Ilha de Santa Catarina e entorno. Ministério do Meio Ambiente, Brasília.

Klein AHF, Short AD, Bonetti J, (2016b) Santa Catatina beach systems, In: Short AD, Klein AHF (Eds) Brazilian Beach Systems. Springer, Switzerland, pp 465-506

Komar PD, Gaughan MK (1972) Airy wave theory and breaker height prediction. In: Coastal Engineering 1972. American Society of Civil Engineers, New York, NY, pp 405-418. https://doi.org/10.1061/9780872620490.023

Kriebel DL, Dean RG (1993) Convolution method for time-dependent beach-profile response. J. Waterw. Port, Coastal, Ocean Eng 119:204-226 https://doi.org/10.1061/(ASCE)0733-950X(1993)119:2(204)

Kron W (2013) Coasts: The high-risk areas of the world. Nat Hazards 66:1363-1382 https://doi.org/10.1007/s11069-012-0215-4

Leal KB, Bonetti J, Pereira P (2020) Influence of beach orientation on shoreline retreat induced by storm surges: Armação and Canasvieiras, Ilha de Santa Catarina - SC. Rev Bras de Geografia Física 13:1730-1753

Lima CO, Bonetti J (2020) Bibliometric analysis of the scientific production on coastal communities' social vulnerability to climate change and to the impact of extreme events. Nat Hazards 102:1589-1610. http://doi.org/10.1007/s11069-020-03974-1

Masselink G, Scott T, Poate T, Russell P, Davidson M, Conley D (2016) The extreme 2013/2014 winter storms: hydrodynamic forcing and coastal response along the southwest coast of England. Earth Surf Process Landforms 41:378-391 https://doi.org/10.1002/esp.3836

Mazzer AM, Dillenburg SR, Souza CR de G (2008) Proposta de método para análise de vulnerabilidade à erosão costeira no sudeste da ilha de Santa Catarina, Brasil Rev Bras Geociências 38:278-294 
Mazzer AM, Dillenburg S (2009) Variações temporais da linha de costa em praias arenosas dominadas por ondas do sudeste da ilha de Santa Catarina (Florianópolis, SC, Brasil). Pesqui. em Geociências 36. https://doi.org/10.22456/1807-9806.17880

Melo Filho E, Hammes GR, Franco D... (2006) Estudo de caso: a ressaca de agosto de 2005 em Santa Catarina, in: II Seminário e Workshop Em Engenharia Oceânica. FURG, Rio Grande, pp 01-20

MMA (2004) Projeto Orla: subsídios para um projeto de gestão. Ministério do Meio Ambiente: Brasília.

Montanari F, Polette M, Queiroz SMP, de Kolicheski MB (2020) Estimating economic impacts of sea level rise in Florianópolis (Brazil) for the year 2100. Int J Environ Clim Chang 10:37-48. https://doi.org/10.9734/ijecc/2020/v10i130174

Morton RA, Gibeaut JC, Paine JG (1995) Meso-scale transfer of sand during and after storms: implications for prediction of shoreline movement. Mar Geol 126:161-179 https://doi.org/10.1016/0025-3227(95)00071-6

Muler M, Bonetti J (2014) An integrated approach to assess wave exposure in coastal areas for vulnerability analysis. Mar Geod 37:220-237 https://doi.org/10.1080/01490419.2014.902886

Mussi CS (2017) Mapeamento da geodiversidade e análise de bens e serviços ecossistêmicos prestados pela plataforma continental de Santa Catarina, Brasil. Universidade Federal de Santa Catarina, Florianópolis, p 162

Mussi CS, Bonetti J, Sperb RM (2018) Coastal sensitivity and population exposure to sea level rise: a case study on Santa Catarina Island, Brazil. J Coast Conserv 22:11171128. https://doi.org/10.1007/s11852-018-0619-8

Narra P, Coelho C, Sancho F, Escudero M, Silva R (2019) Coastal hazard assessments for sandy coasts: appraisal of five methodologies. J Coast Res 35:574-589 https://doi.org/10.2112/JCOASTRES-D-18-00083.1

Neumann B, Vafeidis AT, Zimmermann J, Nicholls RJ, (2015) Future coastal population growth and exposure to sea-level rise and coastal flooding - a global assessment. PLOS One 10, e0118571.

Oliveira UR, de Barletta R do C, Peixoto JRV, Horn Filho NO (2008) Variabilidade morfológica da praia do Pântano do Sul, ilha de Santa Catarina, Brasil. Rev. Bras. Geociências 38:566-576. https://doi.org/10.25249/0375-7536.2008383566576

OSMF (2018) Openstreetmap fundation [www Document]. URL https://www.openstreetmap.org/copyright (accessed 8.20.11).

Parise CK, Calliari LJ, Krusche N (2009) Extreme storm surges in the south of Brazil: atmospheric conditions and shore erosion. Brazil J Oceanography 57:175-188. https://doi.org/10.1590/S1679-87592009000300002

Perini L, Calabrese L, Salerno G, Ciavola P, Armaroli C (2016) Evaluation of coastal vulnerability to flooding: comparison of two different methodologies adopted by the Emilia-Romagna region (Italy). Nat Hazards Earth Syst Sci 16:181-194. https://doi.org/10.5194/nhess-16-181-2016

Plomaritis TA, Ferreira Ó, Costas S (2018) Regional assessment of storm related 
983

984

985

986

987

988

989

990

991

992

993

994

995

996

997

998

999

1000

1001

1002

1003

1004

1005

1006

1007

overwash and breaching hazards on coastal barriers. Coast Eng 134:124-133. https://doi.org/https://doi.org/10.1016/j.coastaleng.2017.09.003

Pollard JA, Spencer T, Brooks SM (2018) The interactive relationship between coastal erosion and flood risk. Prog Phys Geogr Earth Environ 43:574-585. https://doi.org/10.1177/0309133318794498

Rodríguez ÍJL, Lasa CI (2016) Generación de bases de datos climáticos para el análisis de riesgos en las costas de Santa Catarina (Brasil): resumen para gestores. CEPAL.

Rudorff FM, Bonetti Filho J, Moreno DA, Oliveira CAF, Murara PG (2014) Maré de tempestade. Atlas desastr. nat. do estado St. Catarina período 1980 a 2010. 151-154.

Rudorff FM, Bonetti J (2010) Avaliação da suscetibilidade à erosão costeira de praias da ilha de Santa Catarina com base em geoindicadores e técnicas de análise espacial de dados. Brazilian J Aquat Sci Technol 14:9. https://doi.org/10.14210/bjast.v14n1.p920

Sallenger JAH (2000) Storm impact scale for barrier islands. J Coast Res 16:890-895

Santa Catarina (2006) Decreto ${ }^{0} 5.010$, de 22 de dezembro de 2006. Regulamenta a lei n. 13.553 , de 16 de novembro de 2005. Lex: coletânea de legislação e jurisprudência, Florianópolis.

Santa Catarina (2010) Implantação do plano estadual de gerenciamento costeiro: diagnóstico sócio ambiental do setor litoral central. Santa Catarina.

Santos E, Bonetti J (2018) Análise da taxa de variação da linha de costa da Enseada de Tijucas (SC) em diferentes escalas temporais como indicadora de susceptibilidade à inundação costeira. Quaternary and Environmental Geosciences 09:19-25 https://doi.org/10.5380/abequa.v9i2.53650

Scherer MEG, Asmus ML (2016) Ecosystem-based knowledge and management as a tool for integrated coastal and ocean management: a brazilian initiative, in: Journal of Coastal Research. Coastal Education Research Foundation Inc., pp 690-694 https://doi.org/10.2112/SI75-138.1

SEAP (2008) Planos locais de desenvolvimento da maricultura - PLDM's de Santa Catarina. Secretaria Especial de Aquicultura e Pesca da Presidência da República, Brasília.

SED-SC (2018) Cadastro de unidade escolar [www document]. Secr. Estado da Educ. St. Catarina. URL http://serieweb.sed.sc.gov.br/cadueportal.aspx (accessed 11.10.18).

Serafim MB, Bonetti J (2017) Vulnerabilidade das praias do Estado de Santa Catarina a eventos de erosão e inundação costeira: proposta metodológica baseada em um índice multicritério. Quat Environ Geosci 8:36-54 https://doi.org/10.5380/abequa.v8i2.47281

Serafim MB, Siegle E, Corsi AC, Bonetti J (2019) Coastal vulnerability to wave impacts using a multi-criteria index: Santa Catarina (Brazil). J Environ Manage 230:21-32 https://doi.org/10.1016/j.jenvman.2018.09.052

Silveira YG, Bonetti J (2019) Assessment of the physical vulnerability to erosion and flooding in a sheltered coastal sector: Florianopolis Bay, Brazil. Journal of Coastal Conservation 23:303-314. https://doi.org/10.1007/s11852-018-0659-0 
Simó DH, Horn Filho, NO (2004) Caracterização e distribuição espacial das "ressacas" e áreas de risco na ilha de Santa Catarina, SC, Brasil. Gravel 2:93-103

1010

1011

1012

1013

1014

1015

1016

1017

1018

1019

1020

1021

1022

1023

1024

1025

1026

1027

1028

1029

1030

1031

1032

1033

1034

1035

1036

1037

1038

1039

1040

1041

1042

1043

1044

1045

1046

1047

1048

1049

Souza JM, de Vieira VF, Trabaquini K, Dortzbach D, Vieira E (2017) Qualidade geométrica das ortofotos e modelo digital de terreno do levantamento aerofotogramétrico do Estado de Santa Catarina Estudo de caso: Microbacia Alto Cubatão. In: Anais do Simpósio Brasileiro de Sensoriamento Remoto. Campinas: Galoá. 2017. https://proceedings.science/sbsr/papers/qualidade-geometrica-dasortofotos-e-modelo-digital-de-terreno-do-levantamento-aerofotogrametrico-doestado-de-santa-cat?lang=pt-br

Tapsell SM, Penning-Rowsell EC, Tunstall SM, Wilson TL (2002) Vulnerability to flooding: health and social dimensions, in: Phil Trans Royal Soc A: Math Phys Eng Sci pp 1511-1525. https://doi.org/10.1098/rsta.2002.1013

Torronteguy M de C (2002) Sistema Joaquina - Morro das Pedras e praias adjacentes da costa leste da ilha de Santa Catarina: aspectos morfodinâmicos,sedimentológicos e fatores condicionantes. Universidade Federal de Santa Catarina.

Truccolo EC, Franco D, Schettini CAF (2006) The low frequency sea level oscillations in the northern coast of Santa Catarina, Brazil J Coast Res https://doi.org/10.2307/25741633

UNISDR (2009) Terminology on Disaster Risk Reduction, United Nations International Strategy for Disaster Reduction. Geneva, p 35

UNISDR (2018) Economic losses, poverty \& disaster 1988-2017, Centre for Research on the Epidemiology of Disasters. Geneva.

Viavattene C, Micou AP, Owen D, Priest SJ, Parker DJ (2015) RISC-KIT D.2.2 - Library of coastal vulnerability indicators. Guidance Document 136.

Viavattene C, Jiménez JA, Ferreira O, Priest S, Owen D, McCall R (2018) Selecting coastal hotspots to storm impacts at the regional scale: a coastal risk assessment framework. Coast Eng 134:33-47 https://doi.org/10.1016/j.coastaleng.2017.09.002

Vieira da Silva G, Muler M, Prado M, Short A, Klein AH, Toldo E (2016) Shoreline change analysis and insight into the sediment transport path along Santa Catarina island north shore, Brazil J Coast Res 32. https://doi.org/10.2112/JCOASTRES-D15-00164.1

Von Storch H (2014) Storm surges: Phenomena, forecasting and scenarios of change, in: Procedia IUTAM. Elsevier B.V., pp 356-362. https://doi.org/10.1016/j.piutam.2014.01.030

Vousdoukas MI, Mentaschi L, Voukouvalas E, Verlaan M, Jevrejeva S, Jackson LP, Feyen L (2018) Global probabilistic projections of extreme sea levels show intensification of coastal flood hazard. Nat Commun 9:2360. https://doi.org/10.1038/s41467-018-04692-w

Weggel JR (1972) Maximum breaker height for design. In: Coastal Engineering 1972. American Society of Civil Engineers, New York, NY, pp 419-432. https://doi.org/10.1061/9780872620490.024 


\begin{tabular}{|c|c|c|}
\hline Components & Variables extracted from the IBGE dataset & Variable interaction \\
\hline A $(\%)$ & $\begin{array}{c}\text { V1. Permanent private households earning up to } 1 / 2 \\
\text { minimum wage per capita per month } \\
\text { V2. Number of permanent private households }\end{array}$ & $\frac{V 1 * 100}{V 2}$ \\
\hline B & $\begin{array}{c}\text { V3. Total monthly income of permanent private } \\
\text { households } \\
\text { V4. Residents in permanent private households }\end{array}$ & $\frac{V 3}{V 4}$ \\
\hline $\mathrm{C}(\%)$ & $\begin{array}{c}\text { V5. Literate household heads } \\
\text { V6. Total number of household heads }\end{array}$ & $\frac{V 5 * 100}{V 6}$ \\
\hline $\mathrm{D}$ & V4 & $\frac{V 7 * 100}{V 6}$ \\
\hline $\mathrm{E}(\%)$ & V7. Female household heads aged 29 and younger \\
\hline $\mathrm{F}(\%)$ & $\begin{array}{r}\text { V8. Population aged 12 and younger } \\
\text { V9. Population aged 65 and older }\end{array}$ & $\frac{(V 8+V 9) * 100}{V 4}$ \\
\hline
\end{tabular}

Annex B. Level of analytical detail recommended and the simplifications realized for the CRAF1 implementation in the study area

\begin{tabular}{|c|c|c|}
\hline \multirow{2}{*}{ Characteristics } & \multicolumn{2}{|c|}{ Level of analytical detail } \\
\hline & Recommended & Applied \\
\hline Hazard assessment scale & Uniform sectors of $1 \mathrm{~km}$ length & $\begin{array}{l}\text { Sector of up to } 2.5 \mathrm{~km} \text { length } \\
\text { according to the available data. }\end{array}$ \\
\hline Morphological characterization & $\begin{array}{l}\text { A DTM with a fine grid and } \\
\text { high resolution to obtain the } \\
\text { morphological parameters and } \\
\text { the topography to be used in the } \\
\text { flood assessment. }\end{array}$ & $\begin{array}{l}\text { A DTM with vertical resolution } \\
\text { of } 2.5 \mathrm{~m} \text { and several limitations } \\
\text { between the land-water } \\
\text { surfaces. }\end{array}$ \\
\hline Beach profiles & $\begin{array}{l}\text { Cross-shore profiles including } \\
\text { the submerged part as an } \\
\text { extension of the ones obtained } \\
\text { from the emerged beach DTM. }\end{array}$ & $\begin{array}{l}\text { Field data obtained in specific } \\
\text { locations along the emerged } \\
\text { area and empirical relationships } \\
\text { to obtain parameters linked to } \\
\text { the submerged part. }\end{array}$ \\
\hline $\begin{array}{l}\text { Hazard model (inundation } \\
\text { extent) }\end{array}$ & $\begin{array}{l}\text { Bathtub model and overwash } \\
\text { extent model in the case of low- } \\
\text { lying areas. }\end{array}$ & Only the bathtub extent model \\
\hline Wave and water level data & $\begin{array}{l}\text { Long time series (recorded or } \\
\text { hindcast) of wave and water } \\
\text { level data. }\end{array}$ & $\begin{array}{c}\text { A reanalysis database to } \\
\text { provide wave and water level } \\
\text { information in deep and } \\
\text { intermediate waters. }\end{array}$ \\
\hline
\end{tabular}




\begin{tabular}{l|l|l}
\hline & & $\begin{array}{l}\text { Empirical relationships to } \\
\text { obtain wave parameters in } \\
\text { shallow waters. }\end{array}$ \\
\hline Exposure Indicators & $\begin{array}{l}\text { Different sources types, but } \\
\text { normally well actualized } \\
\text { obtained at coarse CORINE- } \\
\text { type scale }\end{array}$ & $\begin{array}{l}\text { Different sources of information } \\
\text { with heterogeneous scale and } \\
\text { resolution degrees. }\end{array}$ \\
\hline
\end{tabular}

Annex C. Values obtained from the exposure analysis

\begin{tabular}{|c|c|c|c|c|c|c|c|c|c|c|}
\cline { 2 - 10 } \multicolumn{1}{c|}{} & \multicolumn{4}{|c|}{ Flood extent } & \multicolumn{5}{c|}{ Erosion extent } \\
\hline $\begin{array}{c}\text { Exposure } \\
\text { indicators }\end{array}$ & $\begin{array}{c}\mathbf{1} \\
\text { Exposure } \\
\text { Vall or } \\
\text { Very } \\
\text { Low }\end{array}$ & $\begin{array}{c}\mathbf{2} \\
\text { Low }\end{array}$ & $\begin{array}{c}\mathbf{3} \\
\text { Moderat } \\
\mathrm{e}\end{array}$ & $\begin{array}{c}\mathbf{4} \\
\text { High }\end{array}$ & $\begin{array}{c}\mathbf{5} \\
\text { Very } \\
\text { High }\end{array}$ & $\begin{array}{c}\mathbf{1} \\
\text { Null } \\
\text { or } \\
\text { Very } \\
\text { Low }\end{array}$ & $\begin{array}{c}\mathbf{2} \\
\text { Low }\end{array}$ & $\begin{array}{c}\mathbf{3} \\
\text { Moder } \\
\text { ate }\end{array}$ & $\begin{array}{c}\mathbf{4} \\
\text { High }\end{array}$ & $\begin{array}{c}\mathbf{5} \\
\text { Very } \\
\text { High }\end{array}$ \\
\hline Land Use & $1.0-1.4$ & $1.4-2.1$ & $2.1-2.6$ & $2.6-3.2$ & $3.2-4.0$ & $\begin{array}{c}0.0- \\
1.0\end{array}$ & $\begin{array}{c}1.0- \\
1.8\end{array}$ & $\begin{array}{c}1.8- \\
2.0\end{array}$ & $\begin{array}{c}2.0- \\
2.3\end{array}$ & $\begin{array}{c}2.3- \\
2.9\end{array}$ \\
\hline $\begin{array}{c}\text { Social } \\
\text { Vulnerability }\end{array}$ & 0.0 & $0.0-1.2$ & $1.2-1.6$ & $1.6-2.2$ & $2.2-2.7$ & 0.0 & $\begin{array}{c}0.0- \\
1.2\end{array}$ & $\begin{array}{c}1.2- \\
1.4\end{array}$ & $\begin{array}{c}1.4- \\
1.9\end{array}$ & $1.9-$ \\
\hline $\begin{array}{c}\text { Transport } \\
\text { System }\end{array}$ & $0.0-64$ & $64-152$ & $152-255$ & $255-367$ & $>367$ & $\begin{array}{c}0.0- \\
9.4\end{array}$ & $9.4-24$ & $24-77$ & $\begin{array}{c}77- \\
142\end{array}$ & $\begin{array}{c}142- \\
240\end{array}$ \\
\hline Business & $0.0-18$ & $18-38$ & $38-84$ & $84-193$ & $>193$ & $\begin{array}{c}0.0- \\
26\end{array}$ & $\begin{array}{c}26- \\
115\end{array}$ & $\begin{array}{c}115- \\
219\end{array}$ & $\begin{array}{c}219- \\
340\end{array}$ & $>340$ \\
\hline Utilities & $0.0-0.3$ & $0.3-1.0$ & $1.0-1.9$ & $1.9-4.1$ & $4.1-9.5$ & & & - & \\
\hline $\begin{array}{c}\text { Overall } \\
\text { Exposure }\end{array}$ & $1.0-1.3$ & $1.3-2.1$ & $2.1-2.7$ & $2.7-3.4$ & $3.4-4.7$ & $\begin{array}{c}0.0- \\
1.3\end{array}$ & $\begin{array}{c}1.3- \\
1.8\end{array}$ & $\begin{array}{c}1.8- \\
2.3\end{array}$ & $\begin{array}{c}2.3- \\
2.9\end{array}$ & $\begin{array}{c}2.9- \\
4.2\end{array}$ \\
\hline
\end{tabular}

1057

1058 Annex D. Land-use classification according the scale developed by Perini et al. (2016)

\begin{tabular}{|c|c|}
\hline Land use classes (Mussi, 2017) & Assigned values \\
\hline $\begin{array}{c}\text { Dense ombrophilous forest } \\
\text { Vegetated dunes } \\
\text { Mangroves } \\
\text { Continental surface waters } \\
\text { Lagoons } \\
\text { Reforestation area } \\
\text { Early-stage undergrowth } \\
\text { Areas without vegetation }\end{array}$ \\
\hline $\begin{array}{c}\text { Free dunes } \\
\text { Sandy beaches }\end{array}$ \\
\hline Croplands \\
\hline Urban settlements \\
\hline \\
\hline
\end{tabular}


LIST OF ABBREVIATIONS

\begin{tabular}{|c|c|}
\hline Abbreviation & Full meaning \\
\hline $\mathrm{BU}$ & Business \\
\hline CI & Coastal Index \\
\hline CNES & National register of health establishments \\
\hline CRAF1 & Coastal Risk Assessment Framework phase one \\
\hline DEINFRA & Infrastructure Department of Santa Catarina' State \\
\hline DHN & Directorate of Hydrography and Navigation \\
\hline G.E.V. & Generalized Extreme Value \\
\hline GIS & Geographic Information System \\
\hline GOST & Global Ocean Surge and Tide database \\
\hline IBGE & Brazilian Institute of Geography and Statistics \\
\hline $\mathrm{I}_{\exp }$ & Exposure indicator \\
\hline $\mathrm{i}_{\mathrm{h}}$ & Hazard indicator \\
\hline IH-AMEVA & Mathematical and Statistical Analysis of Environmental Variables \\
\hline $\mathrm{LU}$ & Land Use \\
\hline RIMPEEX-Sul & $\begin{array}{l}\text { Integrated Network for Monitoring and Forecasting Extreme Events in the } \\
\text { Southern Region }\end{array}$ \\
\hline ROW & Regional Ocean Waves database \\
\hline SC-CC & Santa Catarina Central Coast \\
\hline SDS & $\begin{array}{l}\text { State Secretary of Sustainable Economic } \\
\text { Development }\end{array}$ \\
\hline SEAP & Special Secretariat for Aquaculture and Fisheries \\
\hline SED-SC & Secretary of Education of Santa Catarina's State \\
\hline SV & Social Vulnerability \\
\hline SVI & Social Vulnerability Index \\
\hline $\mathrm{T}$ & Return Period \\
\hline TS & Transport System \\
\hline TWL & Total Water Level \\
\hline UT & Utilities \\
\hline
\end{tabular}

\section{LIST OF SYMBOLS}

\begin{tabular}{|l|l|}
\hline SYMBOL & MEANING \\
\hline A & Parameter governing the profile steepness \\
\hline$A_{i}$ & Area occupied by the land use class \\
\hline$A_{t}$ & Total area of the sector \\
\hline B & Frontal dune height \\
\hline
\end{tabular}




\begin{tabular}{|l|l|}
\hline $\mathrm{D}_{50}$ & Sediment sizes \\
\hline $\mathrm{g}$ & Gravitational acceleration \\
\hline $\mathrm{Hb}$ & Breaking wave height \\
\hline $\mathrm{hb}$ & Break wave depth \\
\hline $\mathrm{k}$ & Dean's constant \\
\hline $\mathrm{m}$ & Beach profile slope \\
\hline $\mathrm{R}_{\infty}$ & Maximum potential retreat \\
\hline $\mathrm{R}_{\mathrm{t}}$ & Potential retreat \\
\hline $\mathrm{S}$ & Water level variation \\
\hline $\mathrm{TD}$ & Storm duration \\
\hline $\mathrm{T}_{\mathrm{S}}$ & Time scale of exponential response \\
\hline $\mathrm{V}$ & Value assigned to the land use class \\
\hline $\mathrm{X}_{\mathrm{b}}$ & Distance from the coast to the wave breaking depth \\
\hline$\beta$ & Ratio between the erosion time scale and the storm duration \\
\hline
\end{tabular}

1062 
Figures

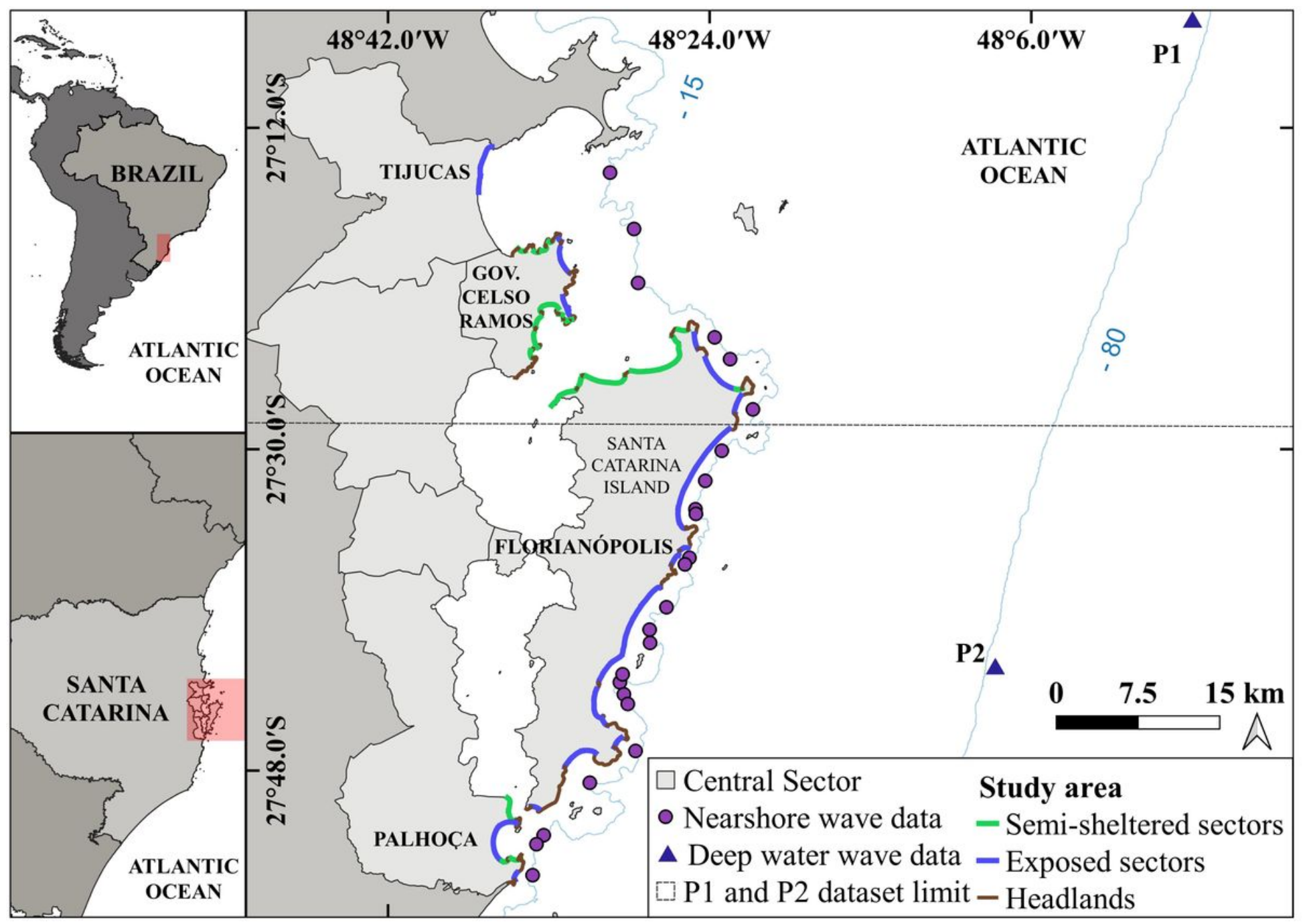

Figure 1

Location of the Santa Catarina Central Coast with sectors classified according to their degree of exposure to the main wave direction. The points used for wave data extraction are also represented. Note: The designations employed and the presentation of the material on this map do not imply the expression of any opinion whatsoever on the part of Research Square concerning the legal status of any country, territory, city or area or of its authorities, or concerning the delimitation of its frontiers or boundaries. This map has been provided by the authors. 


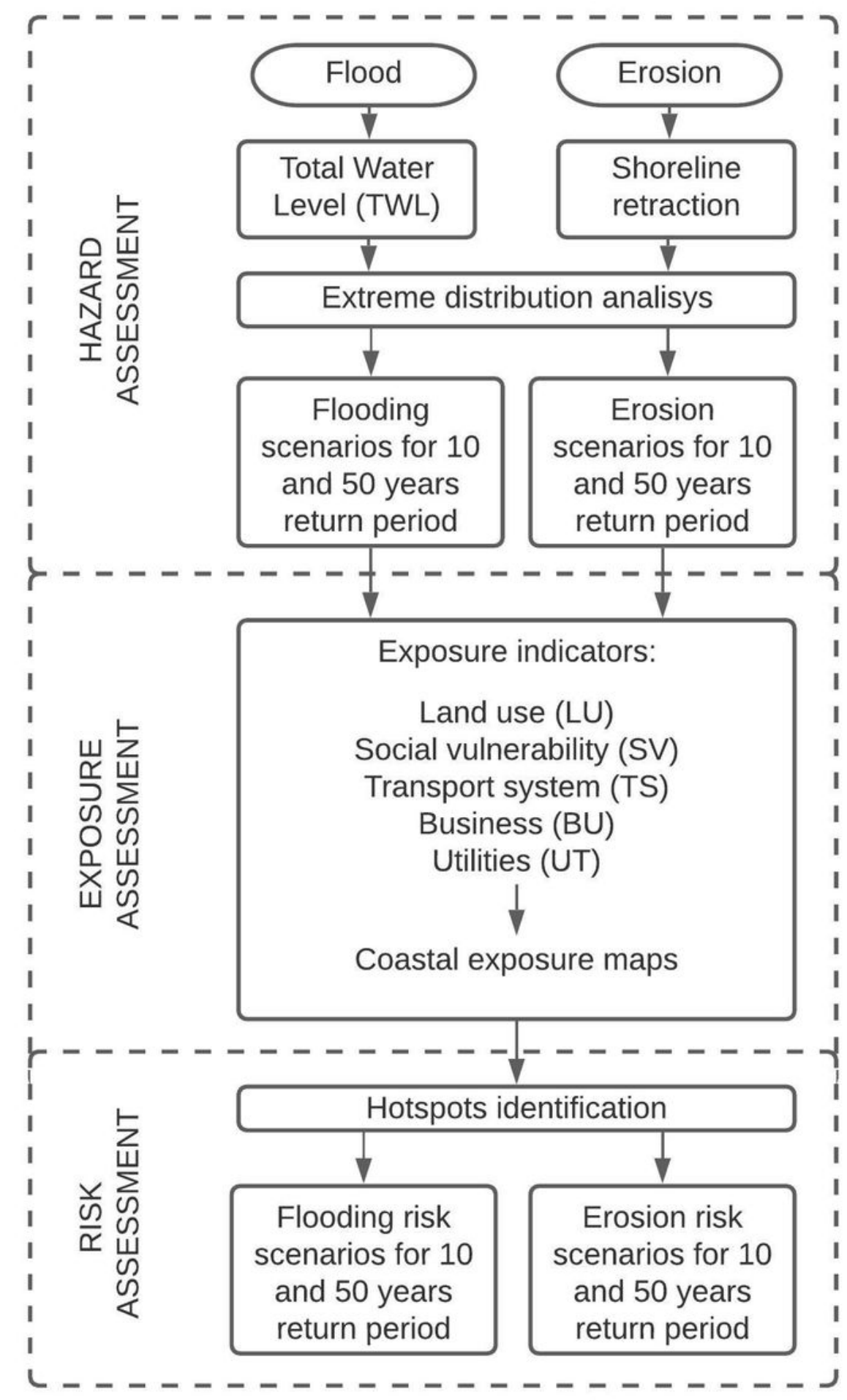

Figure 2

Methodological flowchart of the risk assessment performed in this research. 


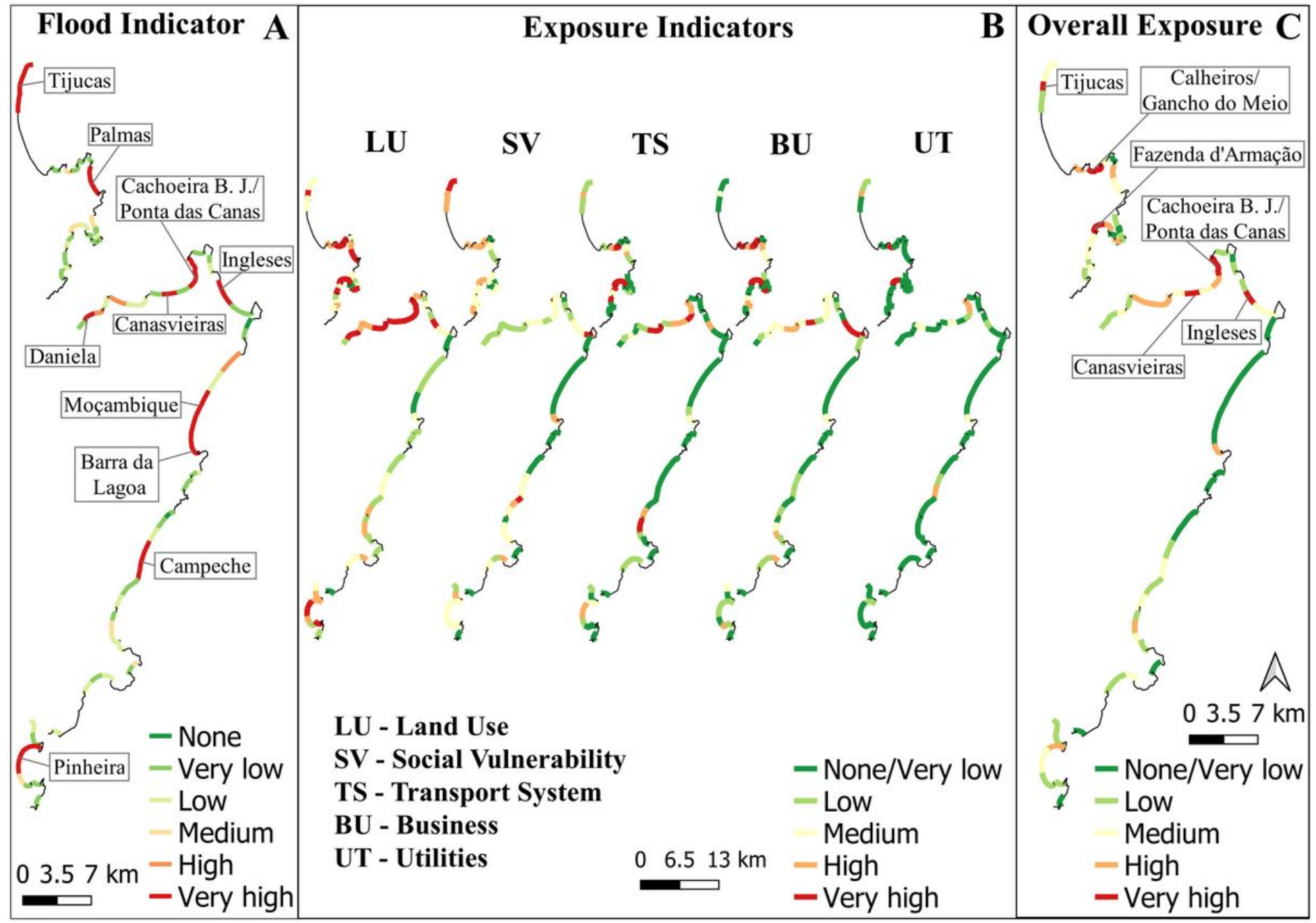

Figure 3

(A) Flood impact and (B; C) exposure indicators for T10 Note: The designations employed and the presentation of the material on this map do not imply the expression of any opinion whatsoever on the part of Research Square concerning the legal status of any country, territory, city or area or of its authorities, or concerning the delimitation of its frontiers or boundaries. This map has been provided by the authors. 


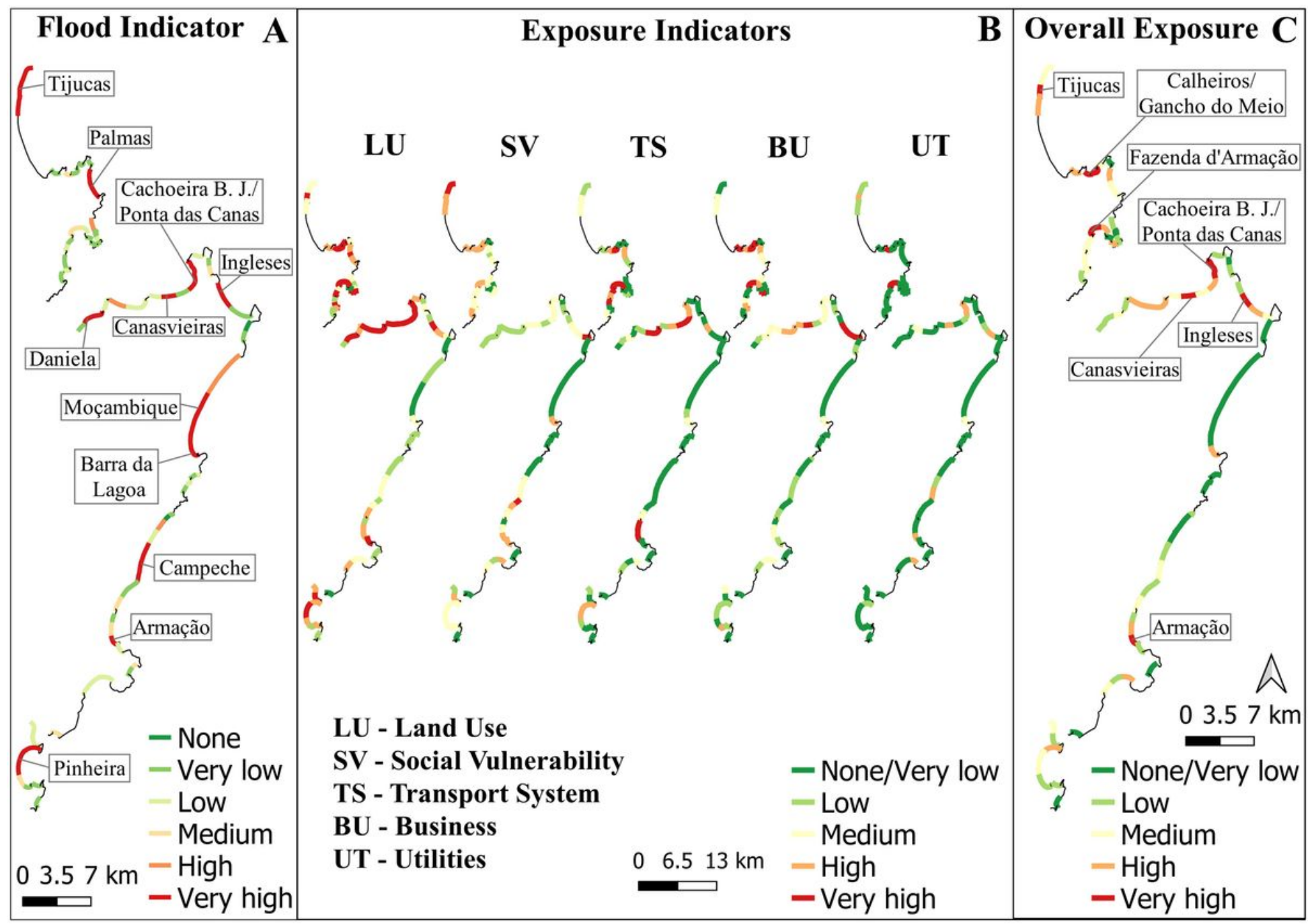

Figure 4

(A) Flood impact and (B; C) exposure indicators for T50 Note: The designations employed and the presentation of the material on this map do not imply the expression of any opinion whatsoever on the part of Research Square concerning the legal status of any country, territory, city or area or of its authorities, or concerning the delimitation of its frontiers or boundaries. This map has been provided by the authors. 


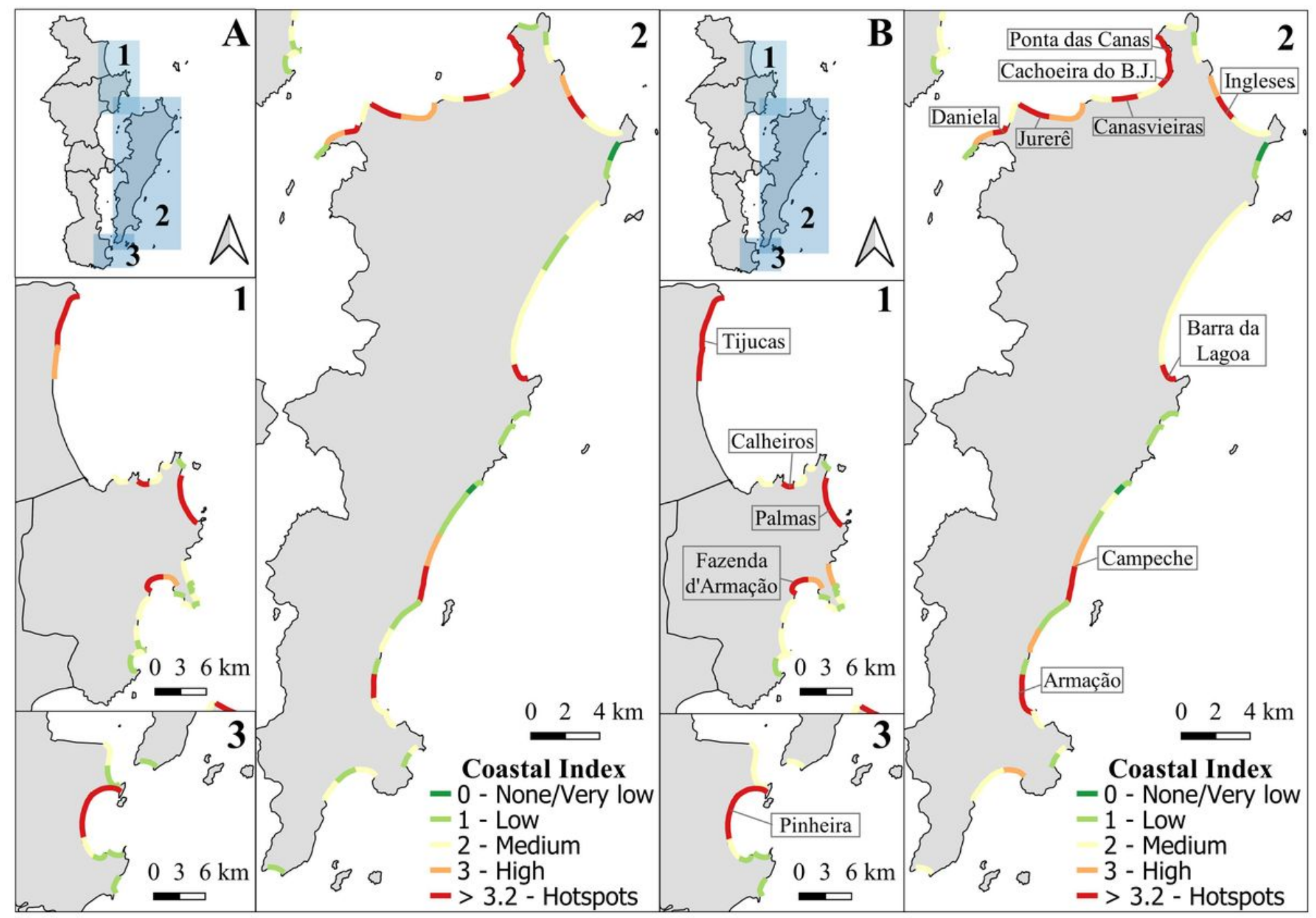

Figure 5

Flood Coastal Index in T10 (A) and T50 (B) scenarios Note: The designations employed and the presentation of the material on this map do not imply the expression of any opinion whatsoever on the part of Research Square concerning the legal status of any country, territory, city or area or of its authorities, or concerning the delimitation of its frontiers or boundaries. This map has been provided by the authors. 


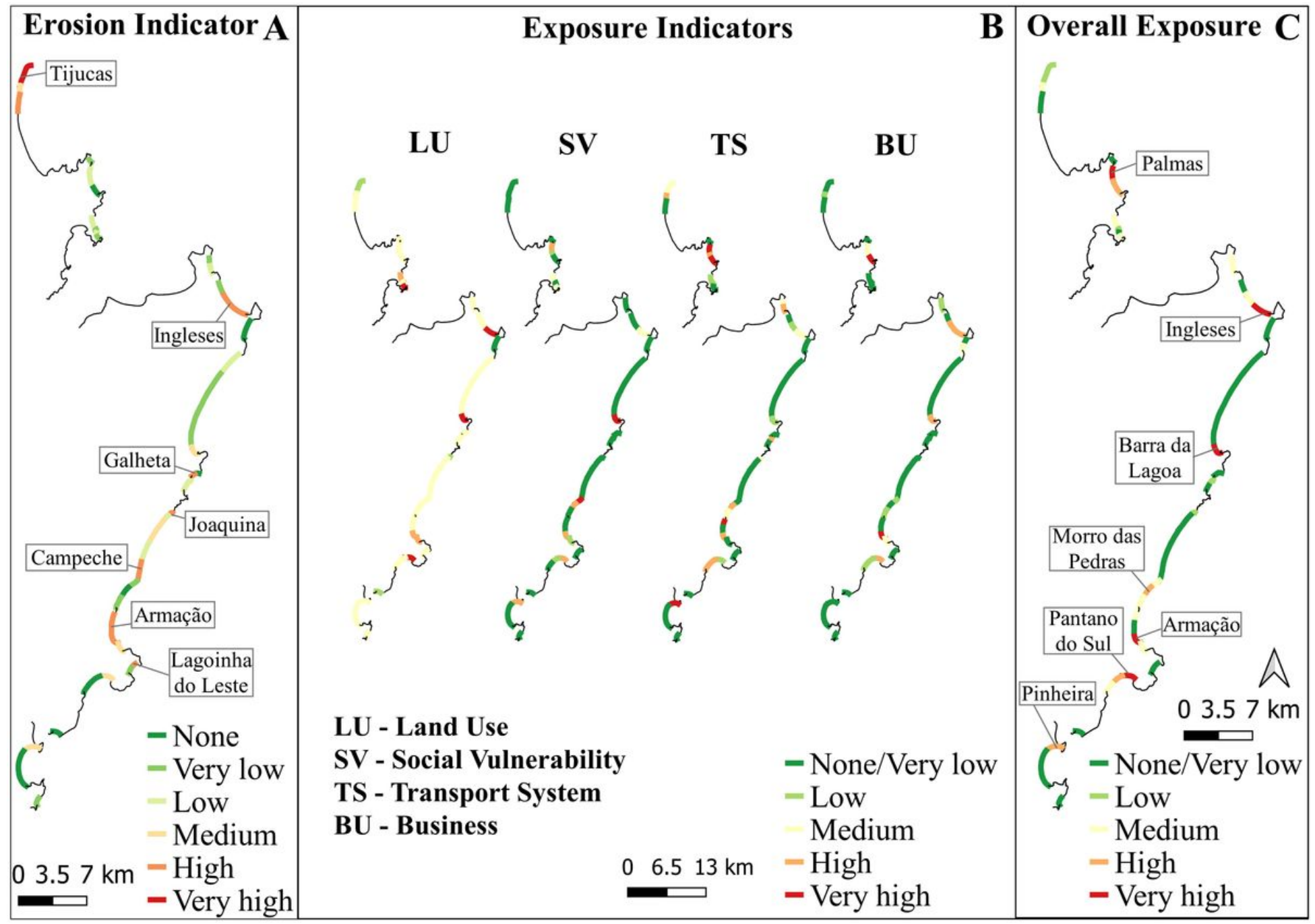

Figure 6

(A) Erosion impact and (B; C) exposure indicators for T10 Note: The designations employed and the presentation of the material on this map do not imply the expression of any opinion whatsoever on the part of Research Square concerning the legal status of any country, territory, city or area or of its authorities, or concerning the delimitation of its frontiers or boundaries. This map has been provided by the authors. 


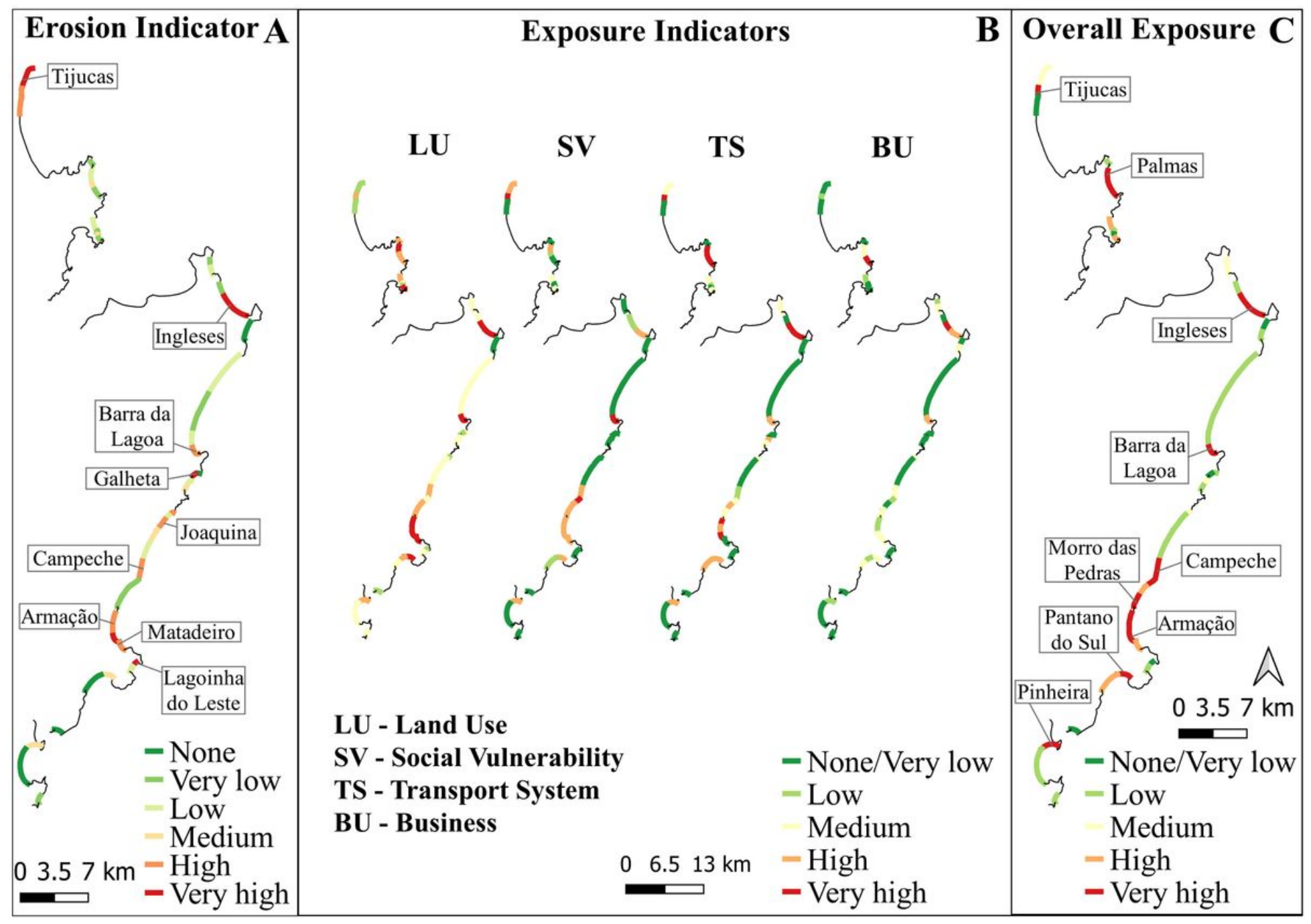

Figure 7

(A) Erosion impact and (B; C) exposure indicators for T50 Note: The designations employed and the presentation of the material on this map do not imply the expression of any opinion whatsoever on the part of Research Square concerning the legal status of any country, territory, city or area or of its authorities, or concerning the delimitation of its frontiers or boundaries. This map has been provided by the authors. 


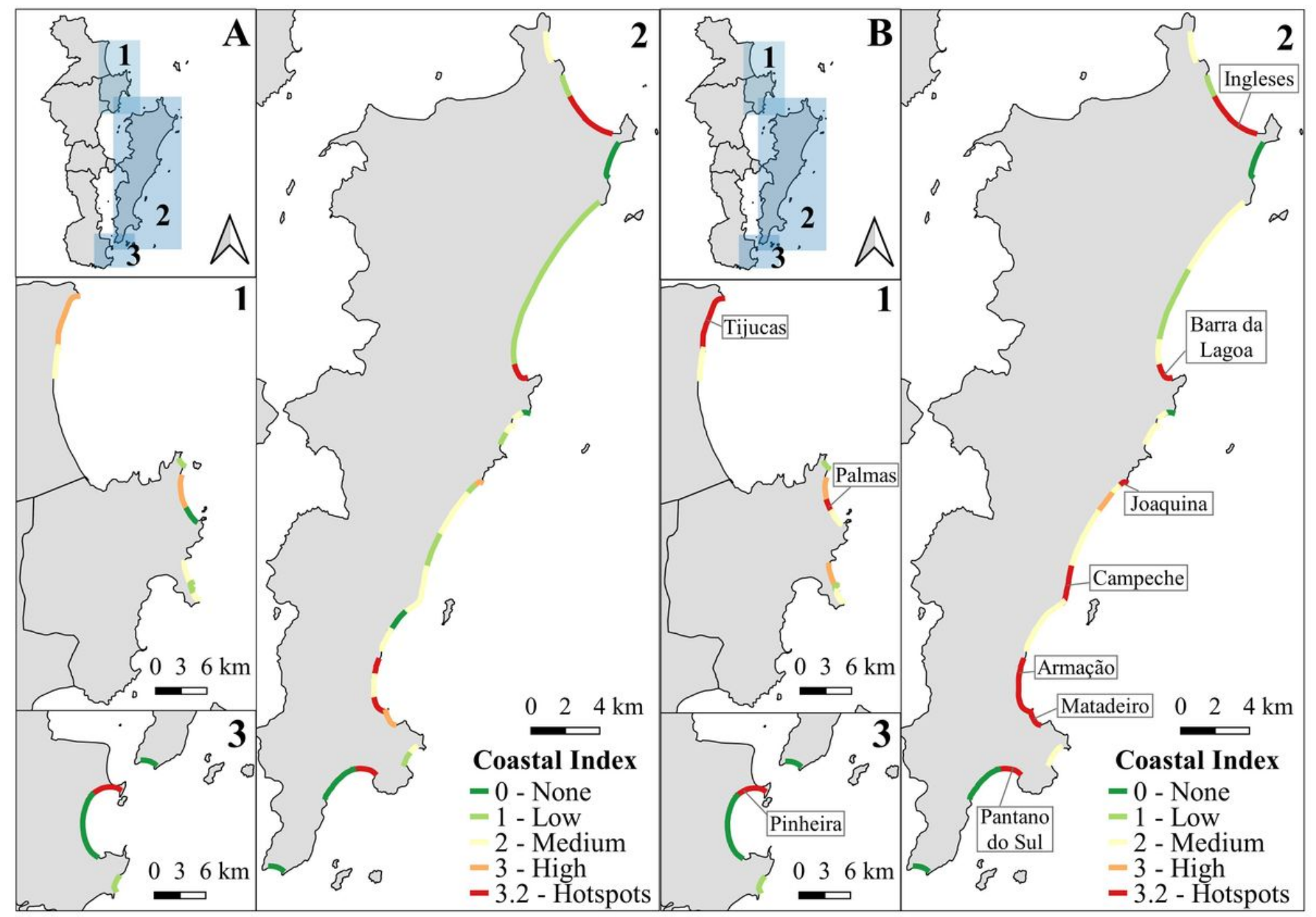

Figure 8

Erosion Coastal Index in T10 (A) and T50 (B) scenarios Note: The designations employed and the presentation of the material on this map do not imply the expression of any opinion whatsoever on the part of Research Square concerning the legal status of any country, territory, city or area or of its authorities, or concerning the delimitation of its frontiers or boundaries. This map has been provided by the authors. 


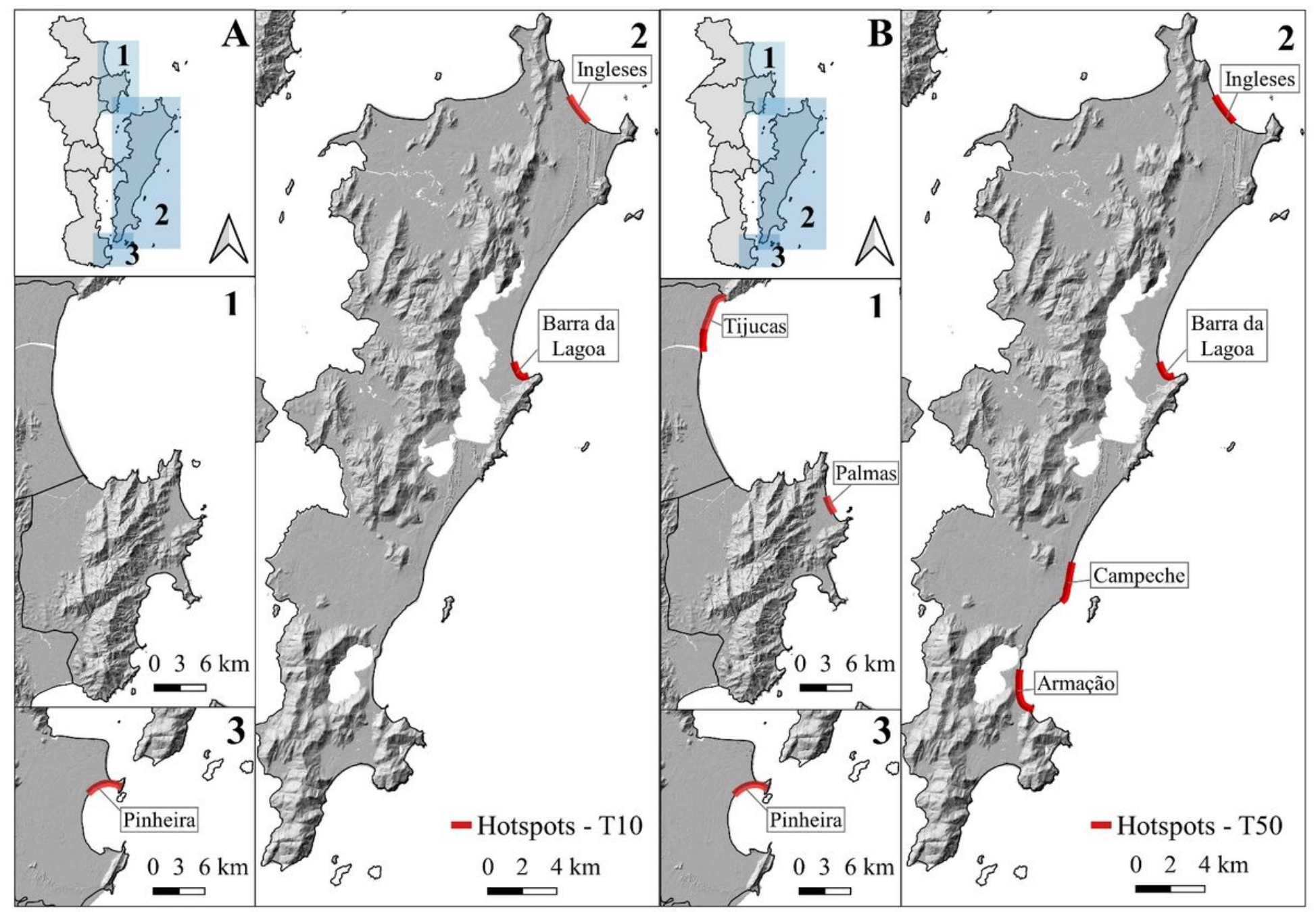

Figure 9

Hotspots that may be submitted simultaneously to very high erosion and flooding hazard impacts in the longer return period scenario (50 years). Note: The designations employed and the presentation of the material on this map do not imply the expression of any opinion whatsoever on the part of Research Square concerning the legal status of any country, territory, city or area or of its authorities, or concerning the delimitation of its frontiers or boundaries. This map has been provided by the authors. 